\title{
A REVIEW OF SOME SOUTH AMERICAN SPECIES OF JUMPING SPI- DERS (ARANEAE: SALTICIDAE) DESCRIBED BY MELLO-LEITÃO FROM BRASIL,WITH RESOLUTION OF THE GENUS ASAPHOBELIS
}

\author{
G. B. Edwards ${ }^{1}$, Isabela M. P. Rinaldi' ${ }^{2}$ and Gustavo R. S. Ruiz ${ }^{3}$
}

Biota Neotropica v5 (n2) - http://www.biotaneotropica.org.br/v5n2/pt/abstract?taxonomic-review+bn01405022005

Date Received 12/17/2004

Revised 03/22/2005

Accepted 07/01/2005

${ }^{1}$ Florida State Collection of Arthropods, Gainesville, Florida, USA, e-mail: edwardg@doacs.state.fl.us ${ }^{2}$ UNESP, Bioscience Institute, Department of Zoology, Botucatu, Brasil, e-mail: rinaldi@ibb.unesp.br ${ }^{3}$ Instituto Butantan, São Paulo, Brasil,e -mail: gustavoruiz86@hotmail.com Corresponding author:

G. B. Edwards - Curator: Arachnida and Myriapoda - Florida State Collection of Arthropods, Division of Plant Industry P.O.Box 147100, 1911 SW 34th St., Gainesville, FL 32614-7100 USA; FAX +01352 334 0737; edwardg@doacs.state.fl.us

\begin{abstract}
The types of 18 species of Salticidae described by Mello-Leitão from Brasil were re-examined and redescribed if necessary. The following nomenclatorial changes are made: New Synonyms: Akela quinquevittata Mello-Leitão $1947=$ Ilargus coccineus Simon 1901; Asaphobelis pluripunctatus Mello-Leitão 1947 = Asaphobelis physonychus Simon 1902; Asaracus elegantulus Mello-Leitão 1947 = Chira thysbe Simon 1902; Breda nigrotaeniata Mello-Leitão $1947=$ Breda flavostriata Simon 1901; Phiale duplocellata Mello-Leitão 1947 = Phiale tristis Mello-Leitão 1945. New Combinations: Akela longibarba Mello-Leitão 1943 = Phiale longibarba (Mello-Leitão 1943); Marpissa broadwayi Peckham \& Peckham 1892 (= Naubolus aureocomosus Mello-Leitão 1943) = Platycryptus broadwayi (Peckham \& Peckham 1892); Saitis labyrintheus Mello-Leitão 1947 = Mopiopia labyrinthea (Mello-Leitão 1947) [lectotype and paralectotype designated]; Saitis tristis Mello-Leitão 1947 = Mopiopia tristis (Mello-Leitão 1947); Semora albibarbis Mello-Leitão 1947 = Tariona albibarbis (Mello-Leitão 1947); Asaphobelis fasciiventris Simon 1902 = Coryphasia fasciiventris (Simon 1902). Asaphobelis physonychus Simon 1902 now is the only species in the genus. Other species redescribed are: Coryphasia castaneipedis Mello-Leitão 1947; Coryphasia nigriventris Mello-Leitão 1947; Cotinusa leucoprocta (Mello-Leitão 1947); Naubolus trifasciatus Mello-Leitão 1927; Phiale bipunctata Mello-Leitão 1947; Pseudofluda pulcherrima Mello-Leitão 1928; Semora langei Mello-Leitão 1947; and Titanattus pallidus Mello-Leitão 1943.
\end{abstract}

Key words: Mello-Leitão, Brasil, Araneae, Salticidae, New Synonyms, New Combinations, Redescriptions.

\section{Resumo}

Os tipos de 18 espécies de Salticidae descritas por Mello-Leitão para o Brasil foram re-examinados e redescritos quando necessário. As seguintes mudanças nomenclaturais foram propostas: Novas sinonímias: Akela quinquevittata Mello-Leitão 1947 = Ilargus coccineus Simon 1901; Asaphobelis pluripunctatus Mello-Leitão 1947 = Asaphobelis physonychus Simon 1902; Asaracus elegantulus Mello-Leitão 1947 = Chira thysbe Simon 1902; Breda nigrotaeniata Mello-Leitão 1947 = Breda flavostriata Simon 1901; Phiale duplocellata Mello-Leitão 1947 = Phiale tristis Mello-Leitão 1945. Novas Combinações: Akela longibarba Mello-Leitão 1943 = Phiale longibarba (Mello-Leitão 1943); Marpissa broadwayi Peckham \& Peckham 1892 (= Naubolus aureocomosus Mello-Leitão 1943) = Platycryptus broadwayi (Peckham \& Peckham 1892); Saitis labyrintheus Mello-Leitão 1947 = Mopiopia labyrinthea (Mello-Leitão 1947) [lectótipo e paralectótipo designados]; Saitis tristis Mello-Leitão 1947 = Mopiopia tristis (Mello-Leitão 1947); Semora albibarbis Mello-Leitão 1947 = Tariona albibarbis (Mello-Leitão 1947); Asaphobelis fasciiventris Simon 1902 = Coryphasia fasciiventris (Simon 1902). Asaphobelis physonychus Simon 1902 agora e a única espécie no gênero. Outras espécies redescritas: Coryphasia castaneipedis Mello-Leitão 1947; Coryphasia nigriventris Mello-Leitão 1947; Cotinusa leucoprocta (MelloLeitão 1947); Naubolus trifasciatus Mello-Leitão 1927; Phiale bipunctata Mello-Leitão 1947; Pseudofluda pulcherrima Mello-Leitão 1928; Semora langei Mello-Leitão 1947; e Titanattus pallidus Mello-Leitão 1943.

Palavras-chave: Mello-Leitão, Brasil, Araneae, Salticidae, novas sinonímias, novas combinações, redescrições. 


\section{Introduction}

Cândido Firmino de Mello-Leitão (see Galiano 1981a for a complete bibliography from 1917-1948) described 27 genera and 239 species of Salticidae from South America, primarily from Argentina and Brasil, but also from Chile, Colombia, Guyana, Paraguay, Uruguay, and Venezuela. Galiano (1980, 1981a) examined the types of all but 30 species (which could not be located), synonymized 107 species, and considered juvenile types of 13 species (and some of the other missing types) to be species inquirendae. She subsequently dealt with a further 25 species (14 new synonyms, 7 new combinations, 2 redescriptions, and 2 designated as nomina dubia; Table 1). However, although she examined the types, Galiano did not provide further information on 61 species, most of which were inadequately described and/or illustrated, and thus were names which remained unavailable to modern workers because they were unrecognizable. Five of these species were later addressed by other authors, and an additional seven species are presently under study elsewhere: Bauab and Soares (1982) created one new combination (Ramboia helenica $=$ Sassacus helenicus), and another species (Dynamius argyrochrysos) was transferred by default when it was recognized that the genus in which it was described was a synonym of Corythalia [in this case, Galiano (1980) had noted that the specimen was incorrectly placed to genus and was more closely related to Phiale]. Edwards (2000) synonymized Fluda usta (Mello-Leitão 1940) with F. perdita (Peckham \& Peckham 1892), and has one included species of Eustiromastix under study (in prep. 2003). Braul \& Lise (2002) reassigned two species described in Vinnius: V. paranaensis Mello-Leitão 1947 was synonymized with Arnoliseus calcarifer (Simon 1902), and V. reticulatus MelloLeitão 1943 was transferred to Chira. Scioscia (in prep. 2002) is working with two species in the genus Lurio. The three species described in the genus Thiodina have been revised (Pires de Melo 2003) but not yet published. One species in the genus Psecas is presently part of a project revising the genus (A. J. Santos and G. Q. Romero, in prep.). We are redescribing (in this and future papers) or otherwise recognizing (e.g., as new synonyms) the remaining 49 species plus Dynamius argyrochrysos mentioned above, for a total of 50 species. In addition, we are transferring one species, Naubolus aureocomosus Mello-Leitão 1943, previously synonymized by Galiano (1981a). Due to the number of species involved, we have divided this project into three papers: (1) those unresolved species from Brasil (the present contribution); (2) the same from Argentina; and (3) the same from Chile, Guyana and Paraguay.

New combinations are made where it is obvious that species need to be transferred, but it is likely that some of these species will be synonymized in the future, or in some cases moved to other genera. Due to the nature of this paper, it would take an inordinate amount of time to do the revisionary work necessary to resolve all the species in all the genera presented here. We have made some synonymies when it was simple to do so, but we leave final resolution of other names to future revisionary work on the individual genera. Our primary purpose here is to make the unresolved species of Mello-Leitão recognizable. Unfortunately, some types remain lost, including the types of Itata partita Mello-Leitão 1930, Metaphidippus coccinelloides Mello-Leitão 1947, and Ramboia helenica Mello-Leitão 1943, so are not dealt with here.

We transfer a Simon (1902) species in order to fully resolve the genus Asaphobelis. This transfer results in the type species, Asaphobelis physonychus Simon 1902, becoming the only remaining species in the genus.

\section{Methods}

The following abbreviations are used in the text:AME = Anterior median eye; $\mathrm{ALE}=$ Anterior lateral eye; $\mathrm{PME}=$ Posterior median eye; PLE = Posterior lateral eye; AERW = Anterior eye row width; PERW = Posterior eye row width; LOQ = Length of ocular quadrangle (ALE-PLE inclusive); OQ = ocular quadrangle (formed by both ALEs and both PLEs); PMEP = Posterior median eye position (as ratio: distance of ALE-PME/ ALE-PLE, i.e., distance of PME from ALE toward PLE); CL = Carapace length; CW = Carapace width; $\mathrm{CH}=$ Carapace height (at $\sim \mathrm{PER})$; AL = Abdomen length; TBL = Total body length; Face $=$ Height of AME + clypeus; Cheeks = Lower anterolateral areas of carapace, below lateral eyes; RTA = retrolateral tibial apophysis; $\mathrm{F}$ = femur; $\mathrm{M}=$ metatarsus; $\mathrm{P}=$ patella; $\mathrm{T}$ = tibia; $\mathrm{d}=$ dorsal; $\mathrm{p}=$ prolateral; $r=$ retrolateral; $v=$ ventral. Marginal macrosetae are indicated by both adjacent surfaces (e.g., dp = dorsoprolateral); legs are listed Roman numerically from anterior to posterior (except for leg formulas). Macrosetae patterns are listed from proximal to distal, for both leg segments and macrosetae arrangements. Numbers per segment (e.g., T v0222; M v022) reflect relative spacing of macrosetae and size of segment. All measurements are in mm. Left palpi are used to illustrate all male palpal characters. Quotes from the descriptions of Mello-Leitão are sometimes included in the descriptions in brackets where there are discrepancies, or to clarify the original condition where there was subsequent damage to a specimen.

Photographs of types were taken with a Nikon Coolpix 995 (GBE) and with an IPEXP4 video camera system (GBE, IMPR). Measurements were taken with the latter system, calibrated for each magnification.

Abbreviations of institutions housing types are given as in Galiano (1980). The name of one Brasilian museum, Instituto de Defesa do Patrimônio Natural (IDPN), has changed to Museu de História Natural Capão da Imbuia (MHNCI). It is located in Curitiba. Localities in the text are given as: Country: State; City and/or other locale. 
Table 1. Mello-Leitão species revised by Galiano from 1981 to 2001.

Mello-Leitão species, year

Akela simplex, 1944

Akela trilineata, 1941

Deloripa canescens, 1944

Eustiromastix obscurus, 1942

Eustiromastix pantherinus, 1942

Freya boeroi, 1945

Freya haemorrhoa, 1945

Hurius tristis, 1944

Ilargus albomaculatus, 1939

Menemerus quadrinotatus, 1939

Menemerus ursinus, 1945

Pensacola variegata, 1939

Phiale ferruginea, 1944

Phiale mutilloides, 1947

Phiale nigrosigillata, 1947

Phiale nigrotaeniata, 1945

Phiale pantherina, 1946

Phiale rubrosericea, 1947

Phiale tristis, 1945

Rhene sexmaculata, 1947

Rudra humilis, 1945

Rudra impatiens, 1945c

Rudra proxima, 1922

Spinurius aeneus, 1941

Theratocyrtus riojanus, 1941 $\underline{\text { Current status if different }}$

Hisukattus simplex (Mello-Leitão 1944)

Simonurius gladifer (Simon 1901)

Menemerus taeniatus (L.Koch 1867)

Sumampattus pantherinus (Mello-Leitão 1942)

Sumampattus pantherinus (Mello-Leitão 1942)

Phiale roburifoliata Holmberg 1875

Phiale gratiosa C.L.Koch 1846

Hisukattus tristis (Mello-Leitão 1944)

Nycerella aprica (Peckham \& Peckham 1896)

Phiale gratiosa C.L.Koch 1846

Phiale gratiosa C.L.Koch 1846

Wedoquella punctata (Tullgren 1905)

Phiale roburifoliata Holmberg 1875

Phiale tristis Mello-Leitão 1945

Phiale tristis Mello-Leitão 1945

Freya nigrotaeniata (Mello-Leitão 1945)

Trydarssus pantherinus (Mello-Leitão 1946)

Phiale tristis Mello-Leitão 1945

Beata aenea (Mello-Leitão 1945)

nomen dubium

nomen dubium

Hurius aeneus (Mello-Leitão 1941)

Aphirape riojana (Mello-Leitão 1941) $\underline{\text { Citation for revision }}$

Galiano 1987

Galiano 1988

Galiano 1984b

Galiano 1983

Galiano 1983

Galiano 1981c

Galiano 1981c

Galiano 1987

Galiano 1982

Galiano 1981c

Galiano 1981c

Galiano 1984a

Galiano 1981c

Galiano 1981b

Galiano 1981b

Galiano 2001

Galiano 1995

Galiano 1981b

Galiano 1981b

Galiano 1992

Galiano 1984c

Galiano 1984c

Galiano 1984c

Galiano 1985

Galiano 1981d 


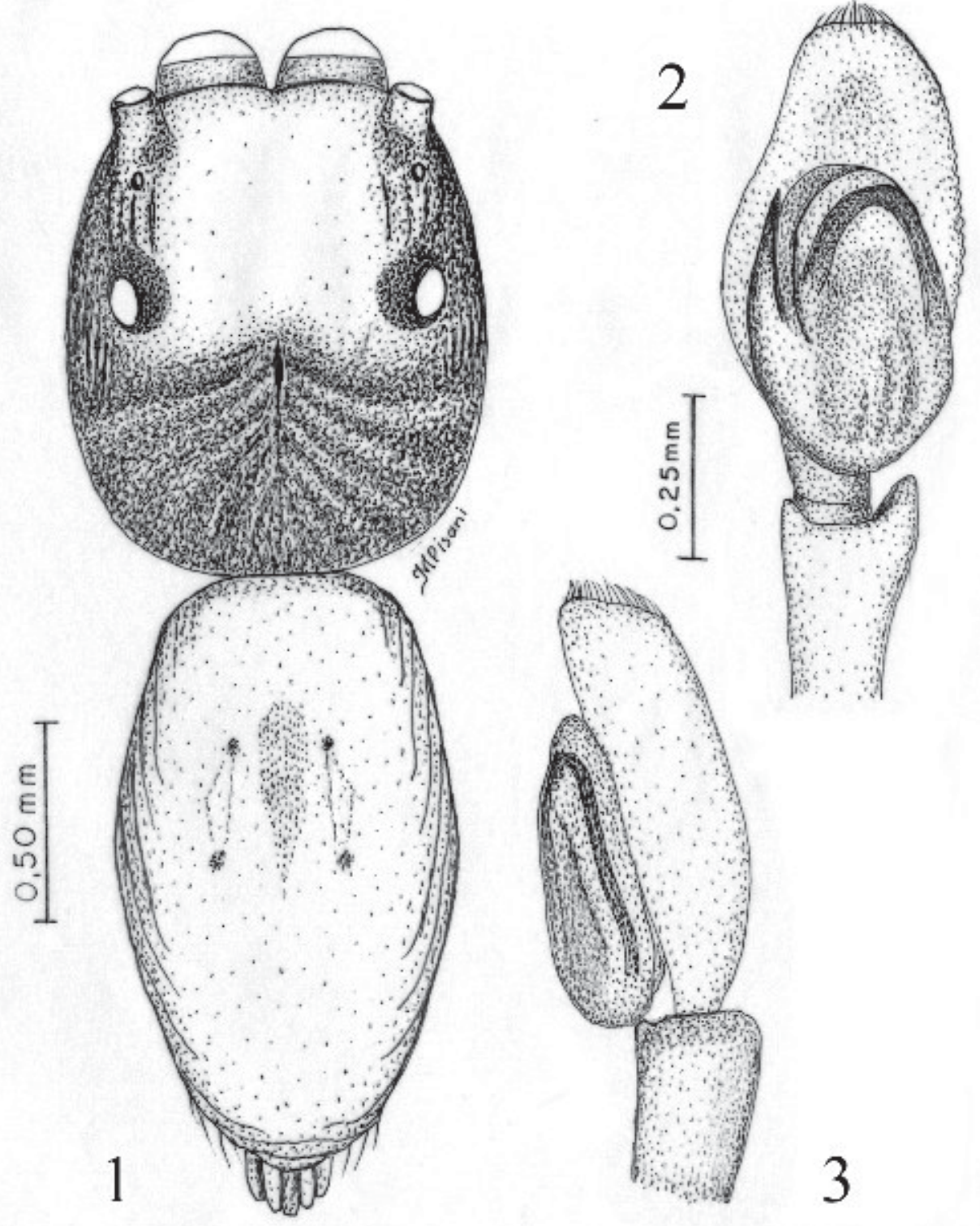

Figures 1-3: Titanattus pallidus 1. male habitus dorsal view; 2. palp ventral view; 3. palp retrolateral view. 

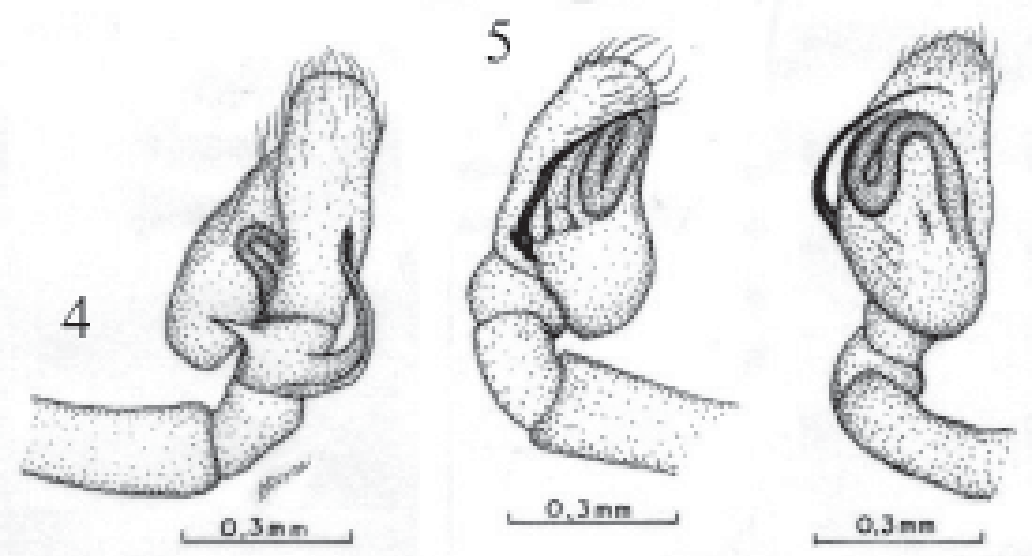

6

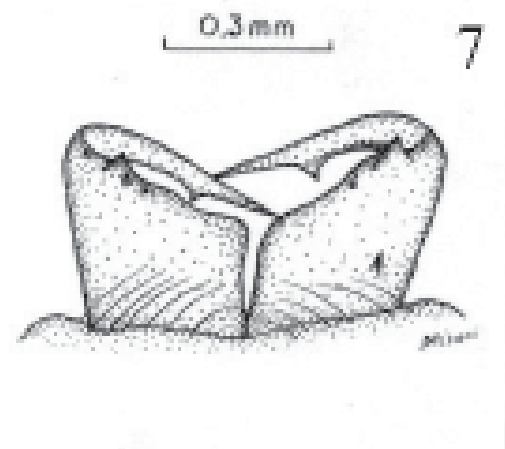

Figures 4-7: Cotinusa leucoprocta 4. male palp retrolateral view; 5. palp prolateral view; 6. palp ventral view; 7. chelicerae ventral view.
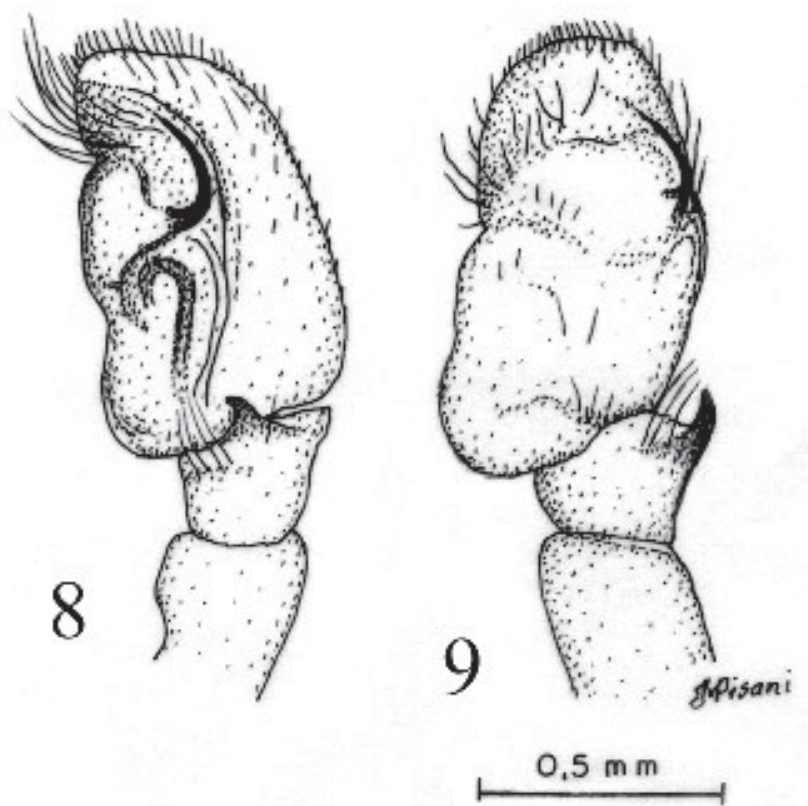

Figures 8-9: Naubolus trifasciatus 8. male palp retrolateral view; 9. palp ventral view.

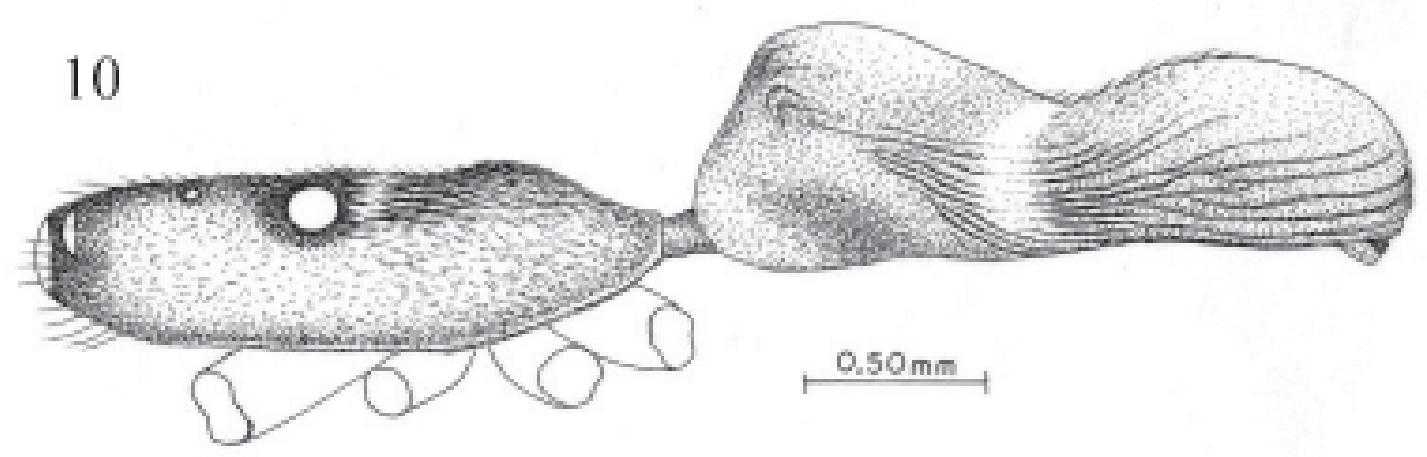

http://www.biotaneotropica.org.br 

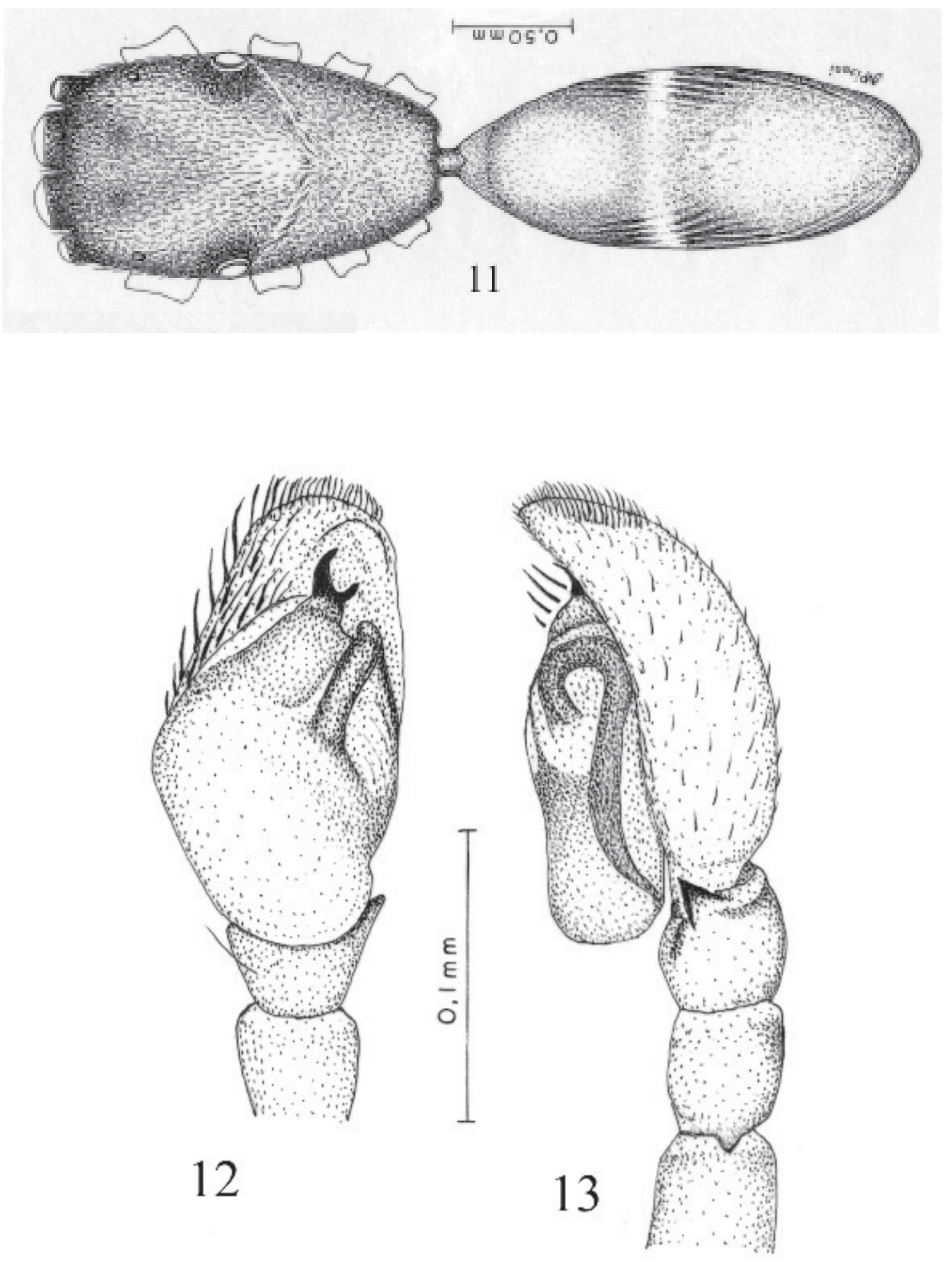

Figures 10-13: Pseudofluda pulcherrima 10. male habitus lateral view; 11. male habitus dorsal view; 12. palp ventral view; 13. palp retrolateral view. 

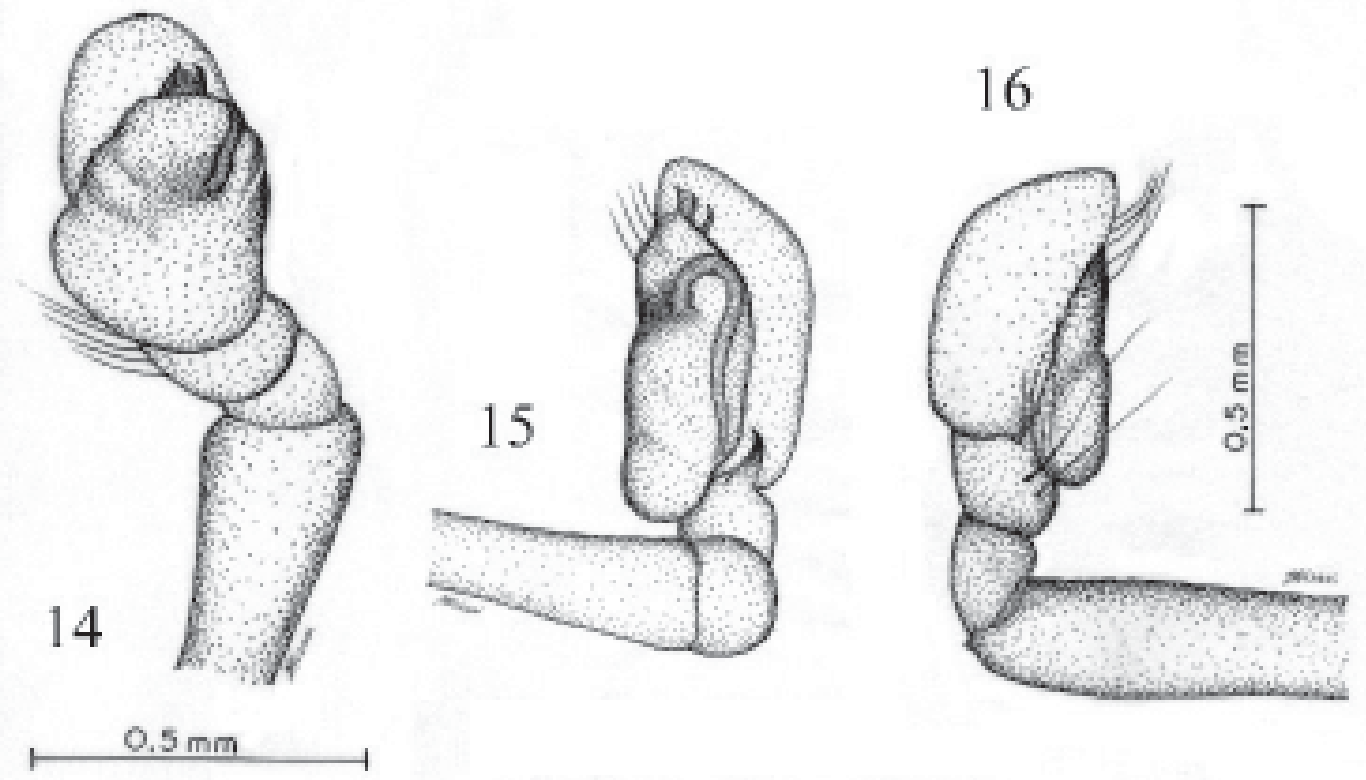

Figures 14-16: Semora langei 14. male palp ventral view; 15. palp retrolateral view; 16. palp prolateral view.
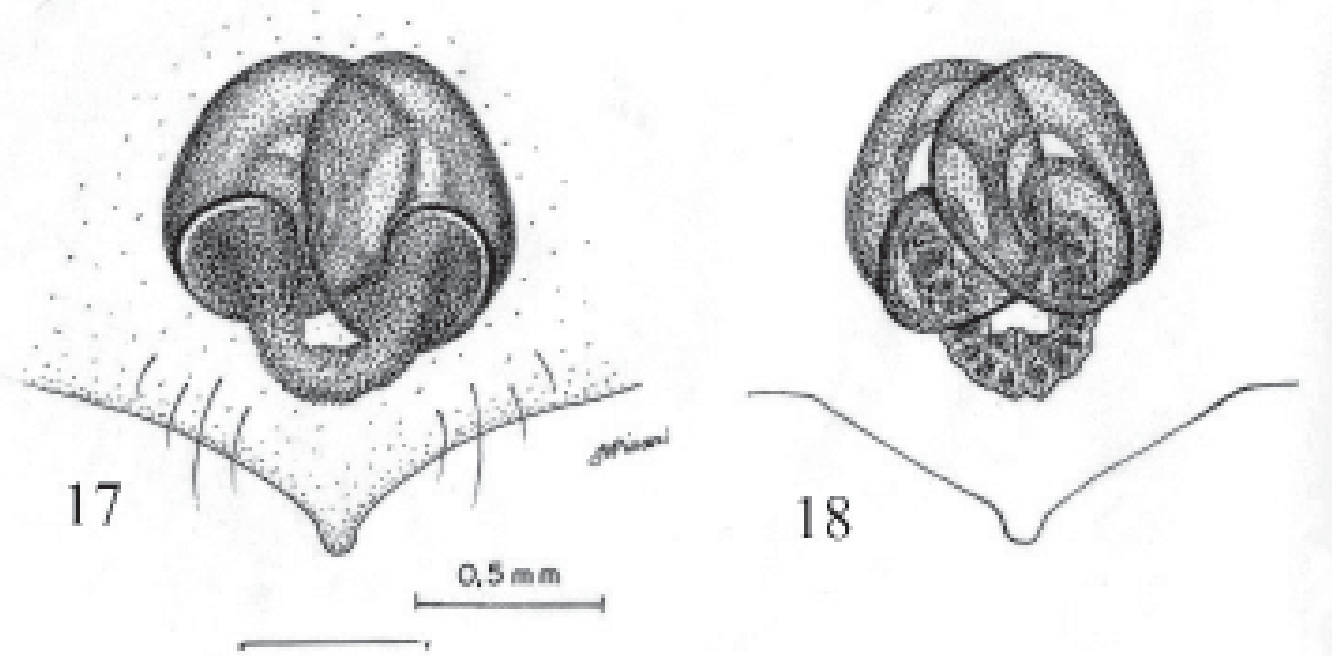

Figures 17-18: Breda flavostriata (Breda nigrotaeniata holotype) 17. female epigynum ventral view; 18. epigynum dorsal view.

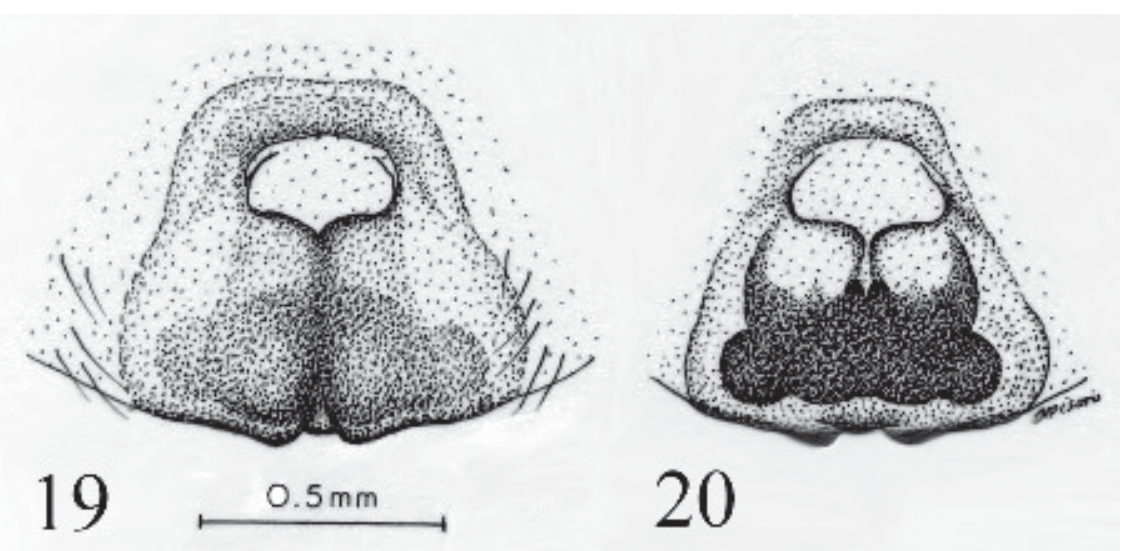

Figures 19-20: Platycryptus broadwayi (Naubolus aureocomosus holotype) 19. female epigynum ventral view; 20. epigynum dorsal view. 

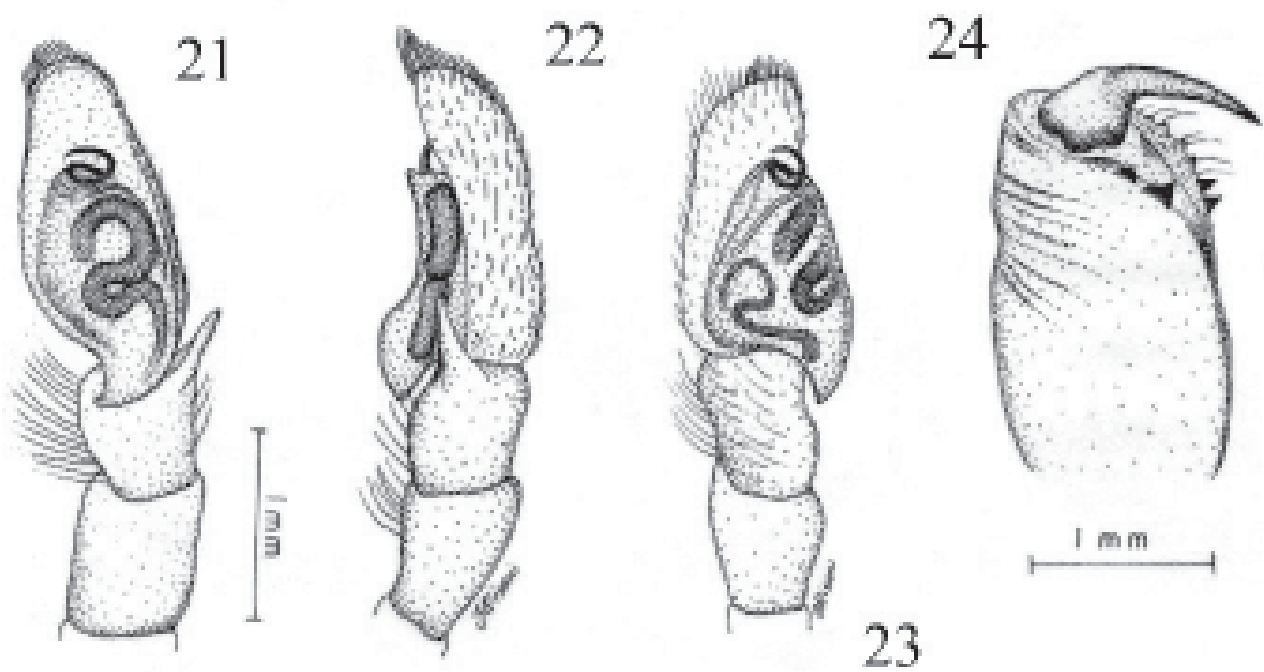

Figures 21-24: Coryphasia castaneipedes 21. male palp ventral view; 22. palp retrolateral view; 23. palp prolateral view; 24. chelicera ventral view.
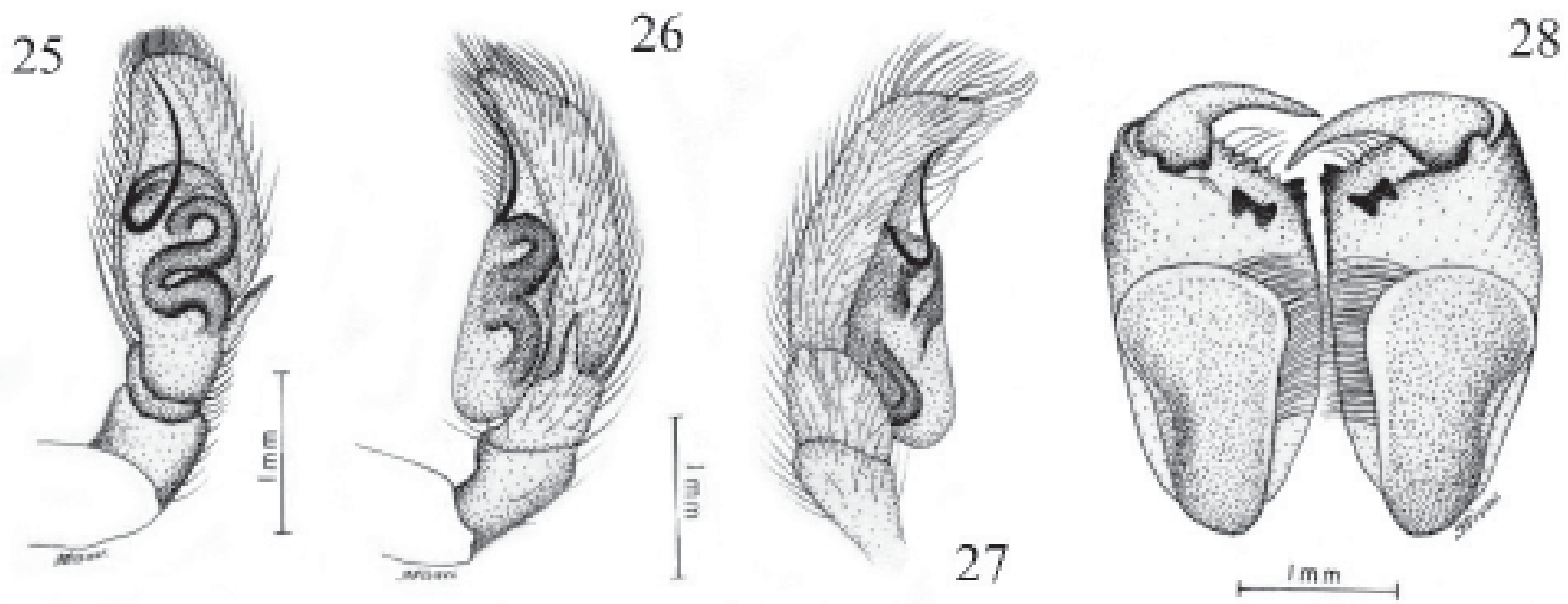

Figures 25-28: Coryphasia nigriventris 25. male palp ventral view; 26. palp retrolateral view; 27. palp prolateral view; 28. chelicera ventral view. 

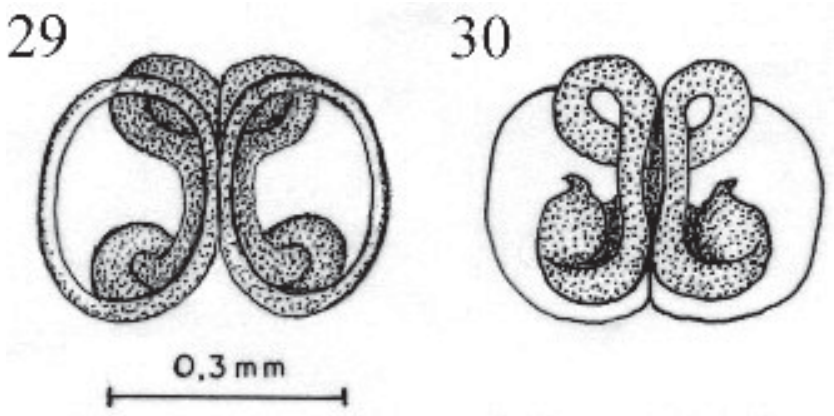

Figures 29-30: Ilargus coccineus (Akela quinquevittata holotype) 29. female epigynum ventral view; 30. epigynum dorsal view.
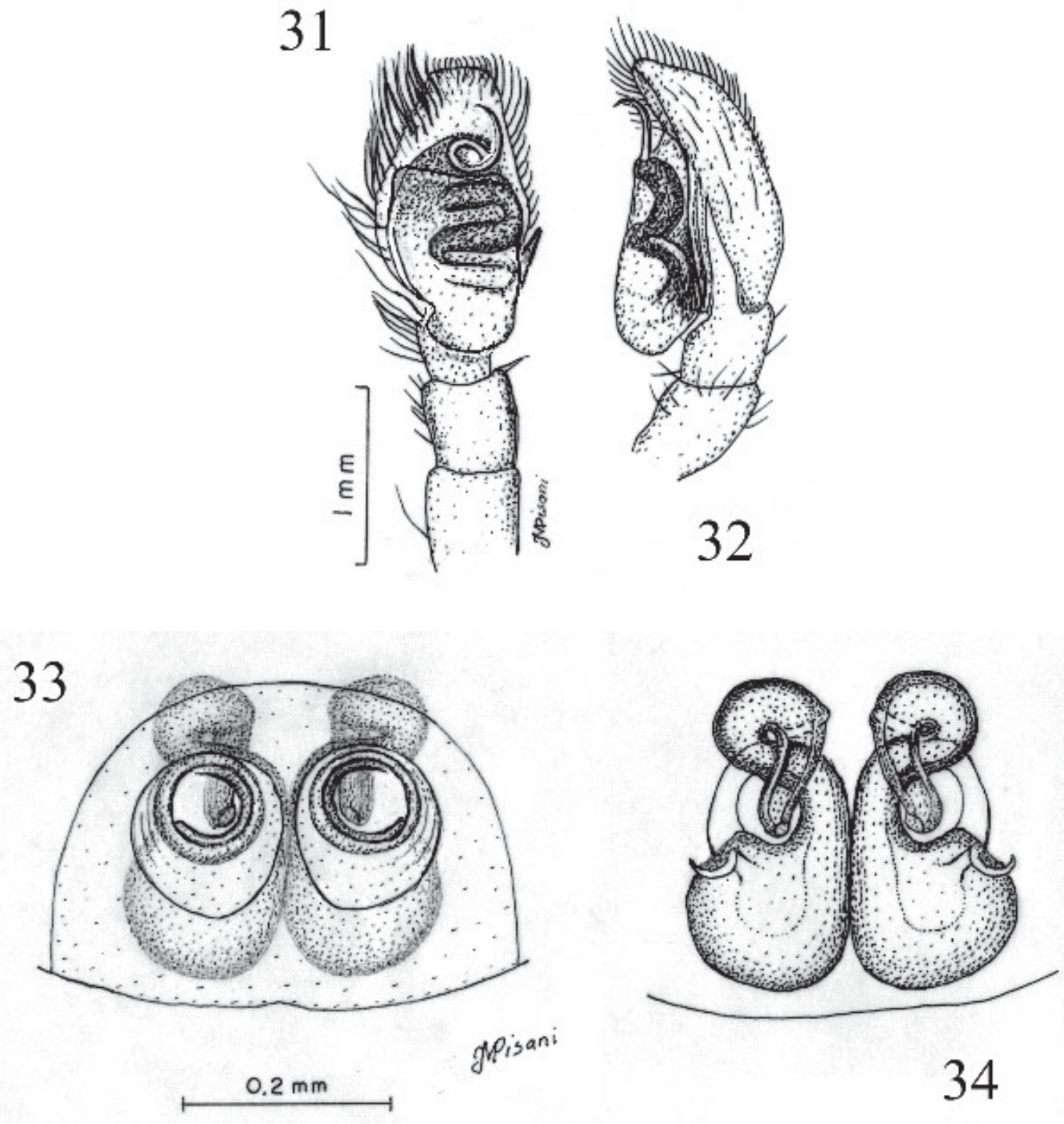

Figures 31-34: Mopiopia labyrinthea 31. male palp ventral view; 32. palp retrolateral view; 33. epigynum ventral view; 34. epigynum dorsal view.

http://www.biotaneotropica.org.br 

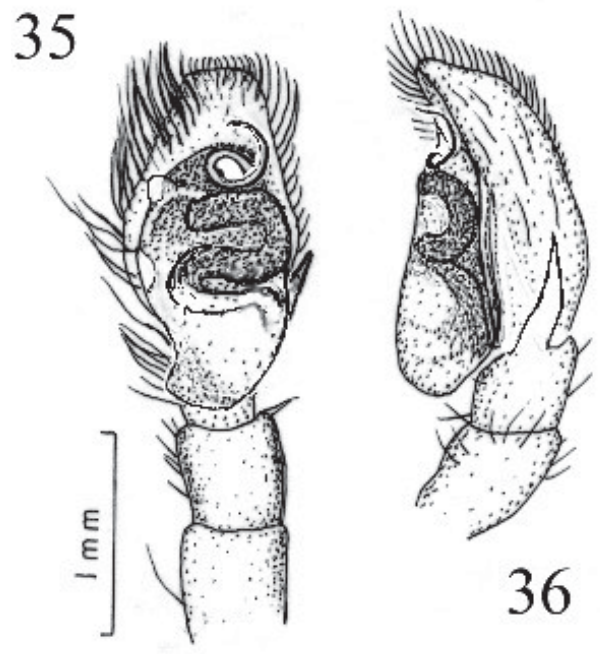

Figures 35-36: Mopiopia tristis 35. male palp ventral view; 36. palp retrolateral view.
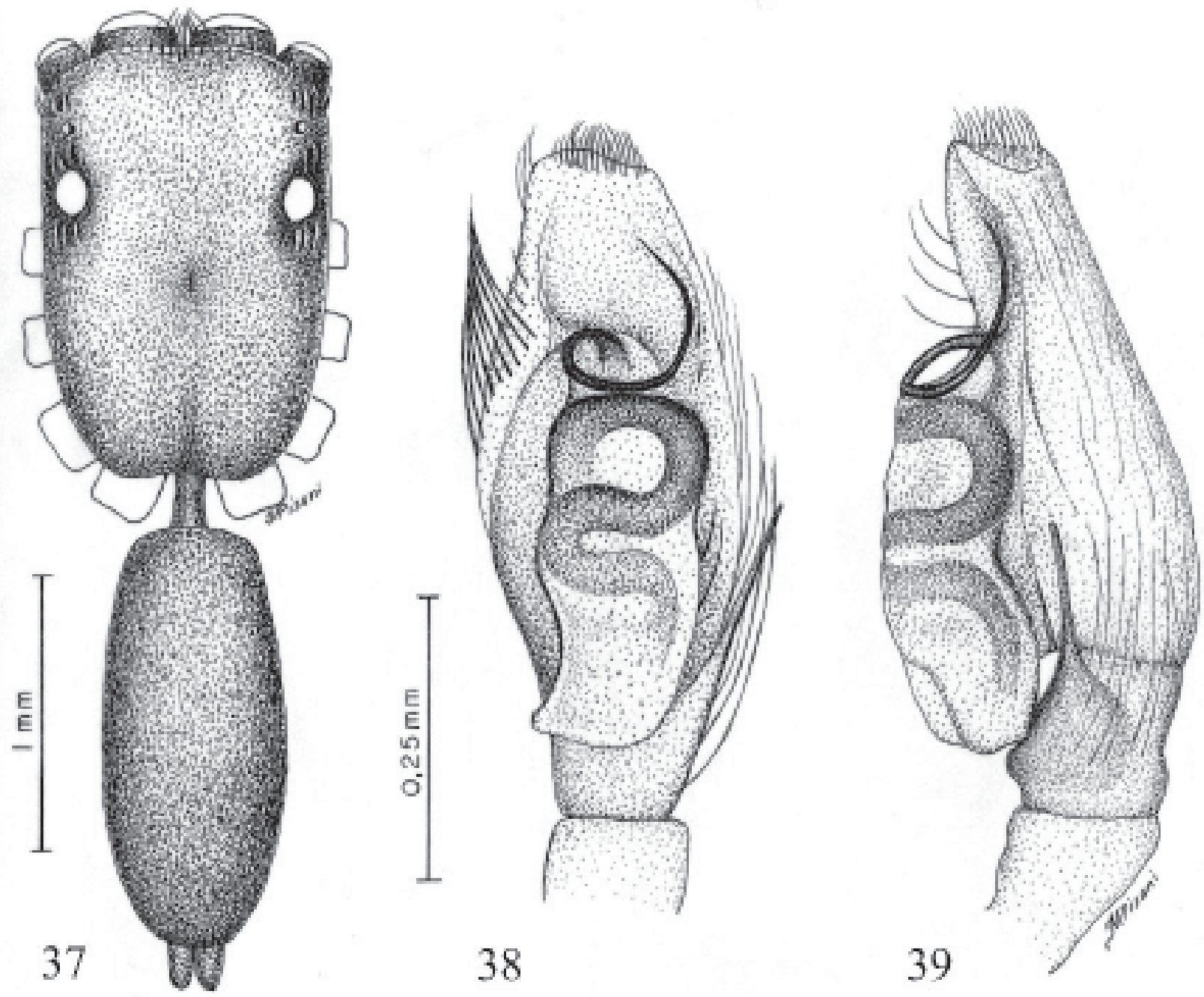

Figures 37-39: Tariona albibarbis 37. male habitus dorsal view; 38. male palp ventral view; 39. palp retrolateral view. 


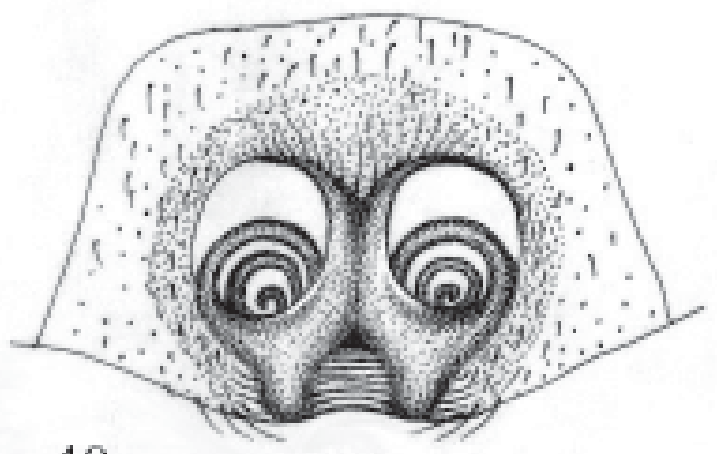

40

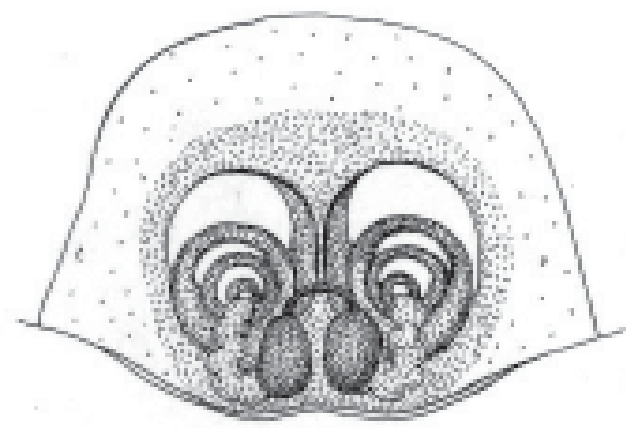

41

Figures 40-41: Phiale bipunctata 40. female epigynum ventral view; 41. epigynum dorsal view.
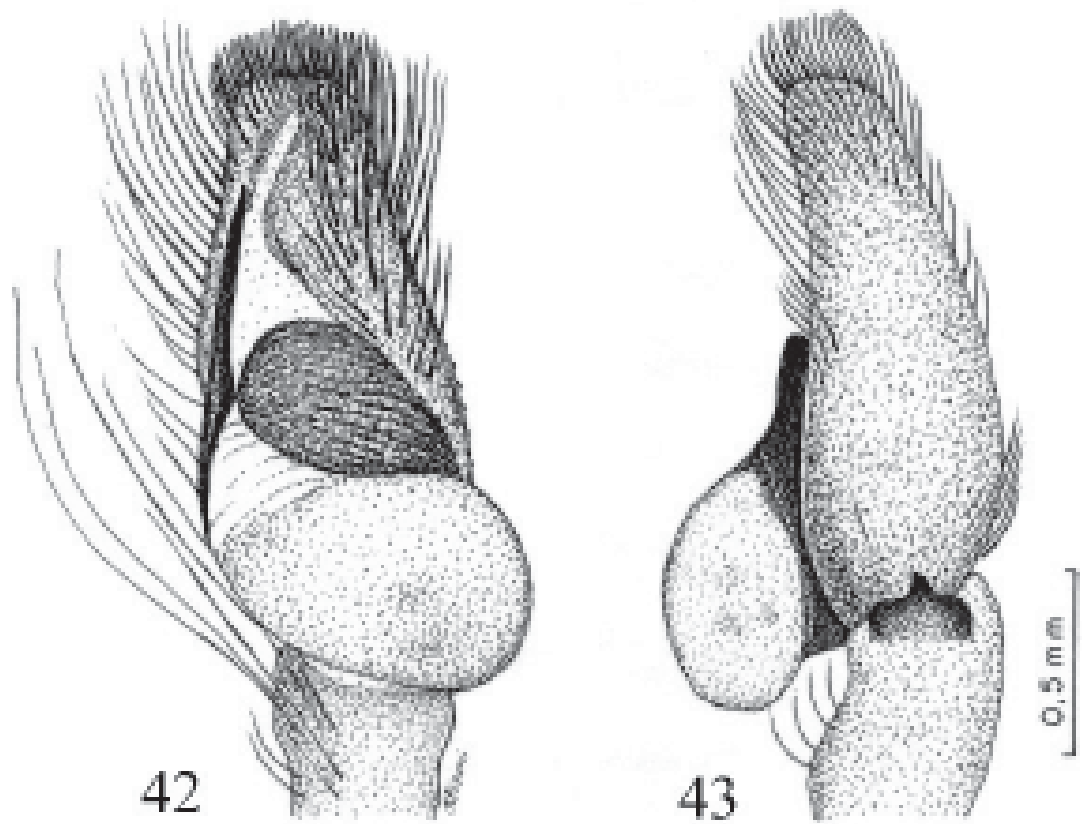

Figures 42-43: Phiale longibarba 42. male palp ventral view; 43. palp retrolateral view.

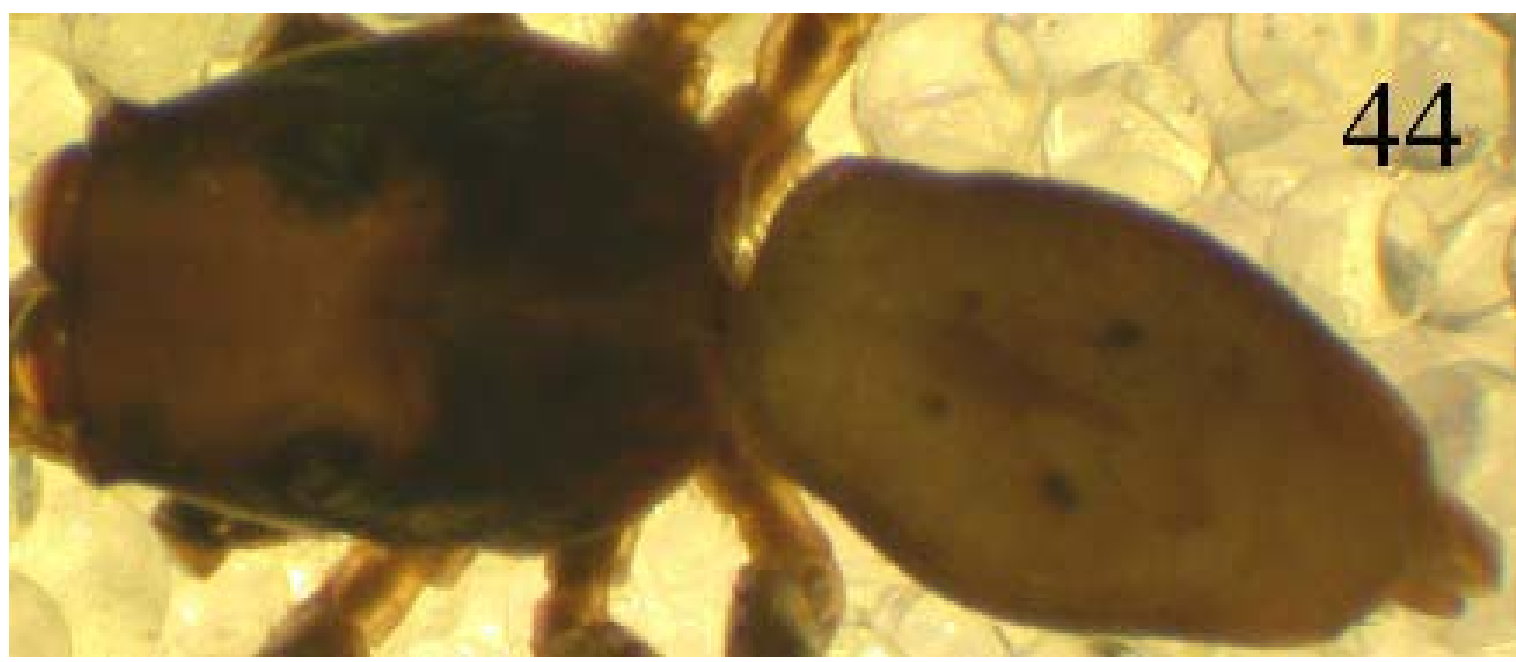

http://www.biotaneotropica.org.br 

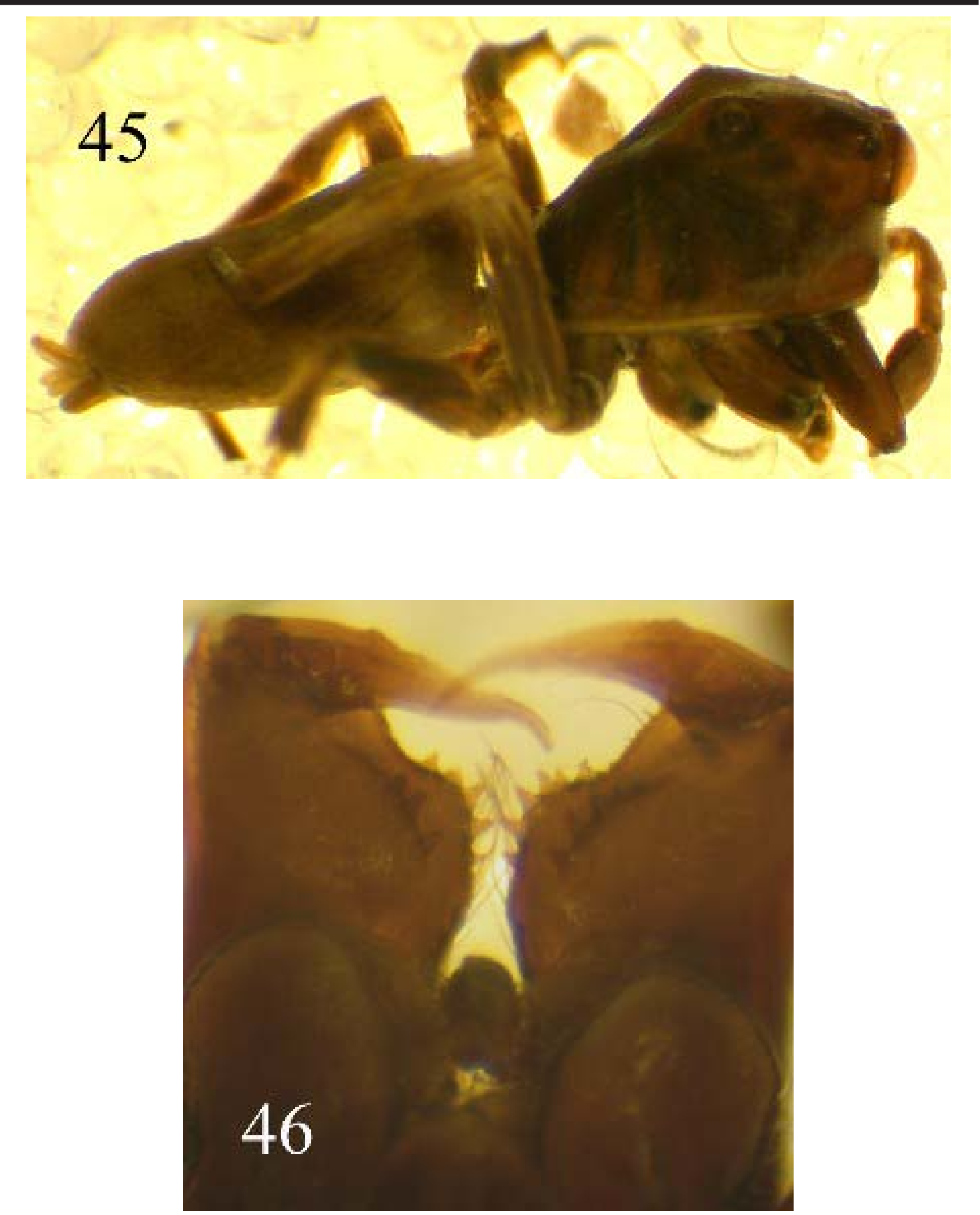

Figures 44-46. Titanattus pallidus male habitus dorsal view; 45. male habitus lateral view; 46. chelicerae ventral view. 


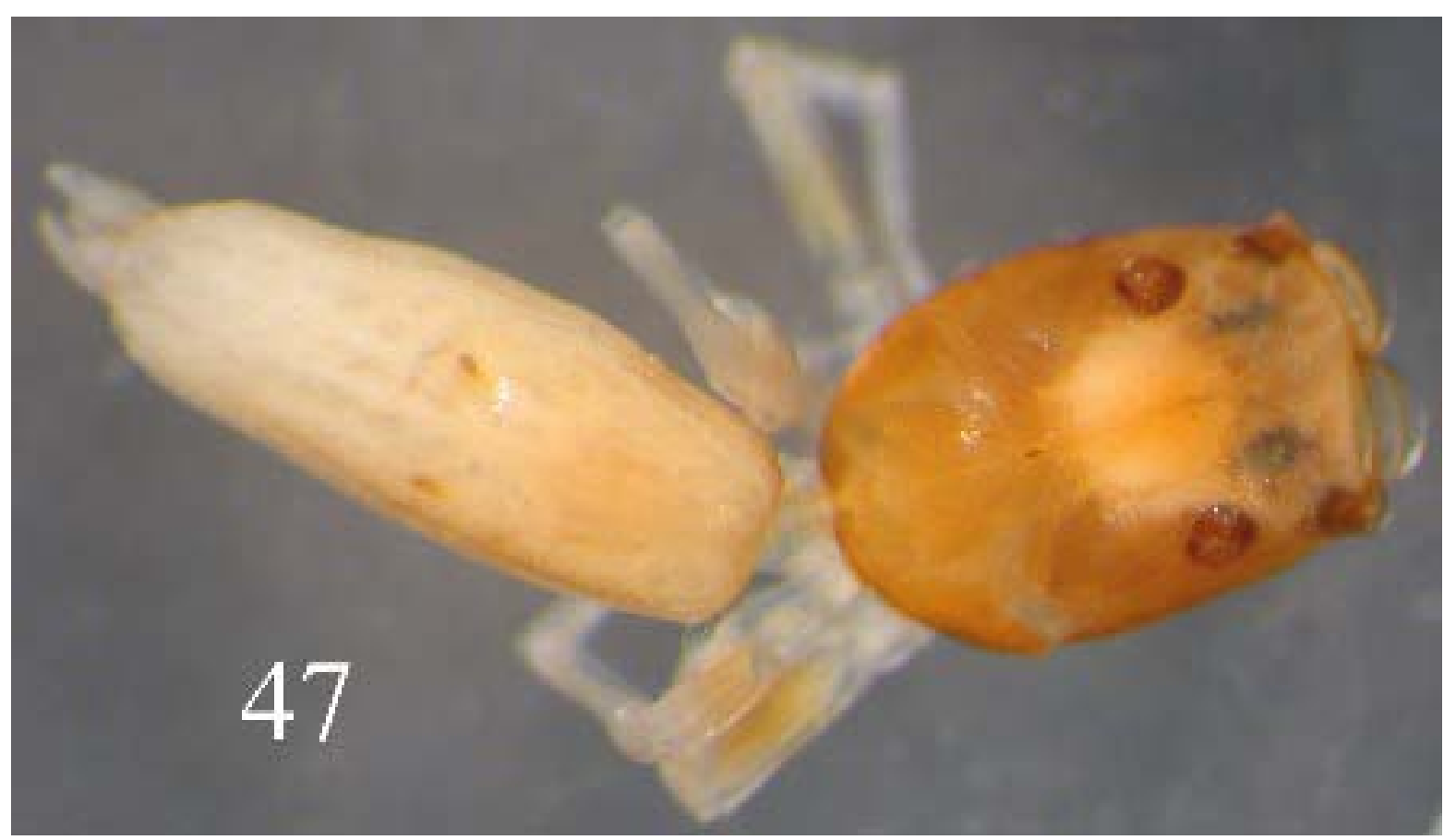

Figure 47. Cotinusa leucoprocta male habitus dorsal view.

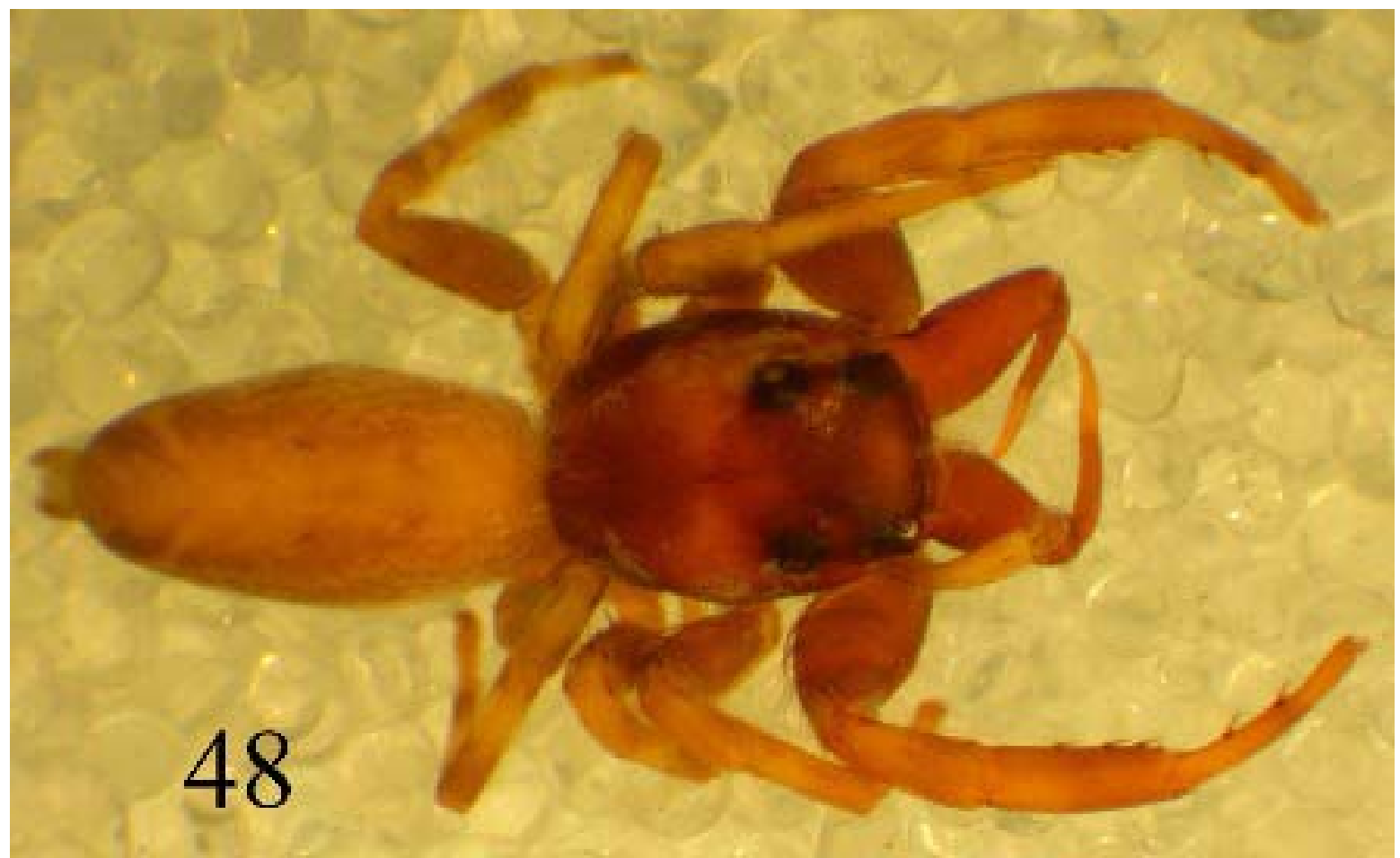

Figure 48. Naubolus trifasciatus male habitus dorsal view.

http://www.biotaneotropica.org.br 


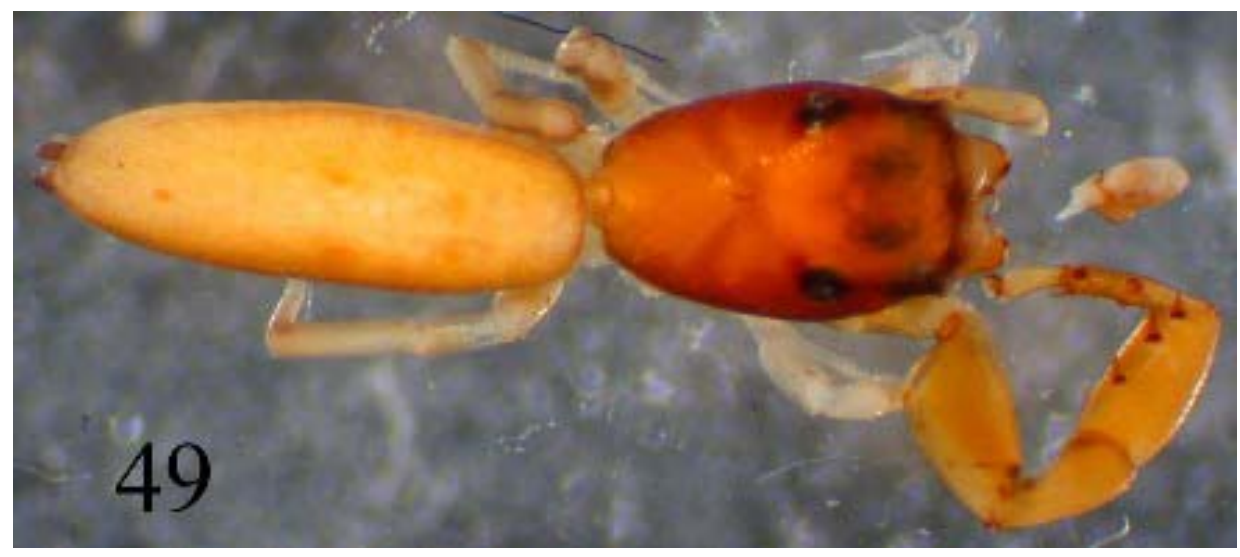

Figure 49. Semora langei male habitus dorsal view.

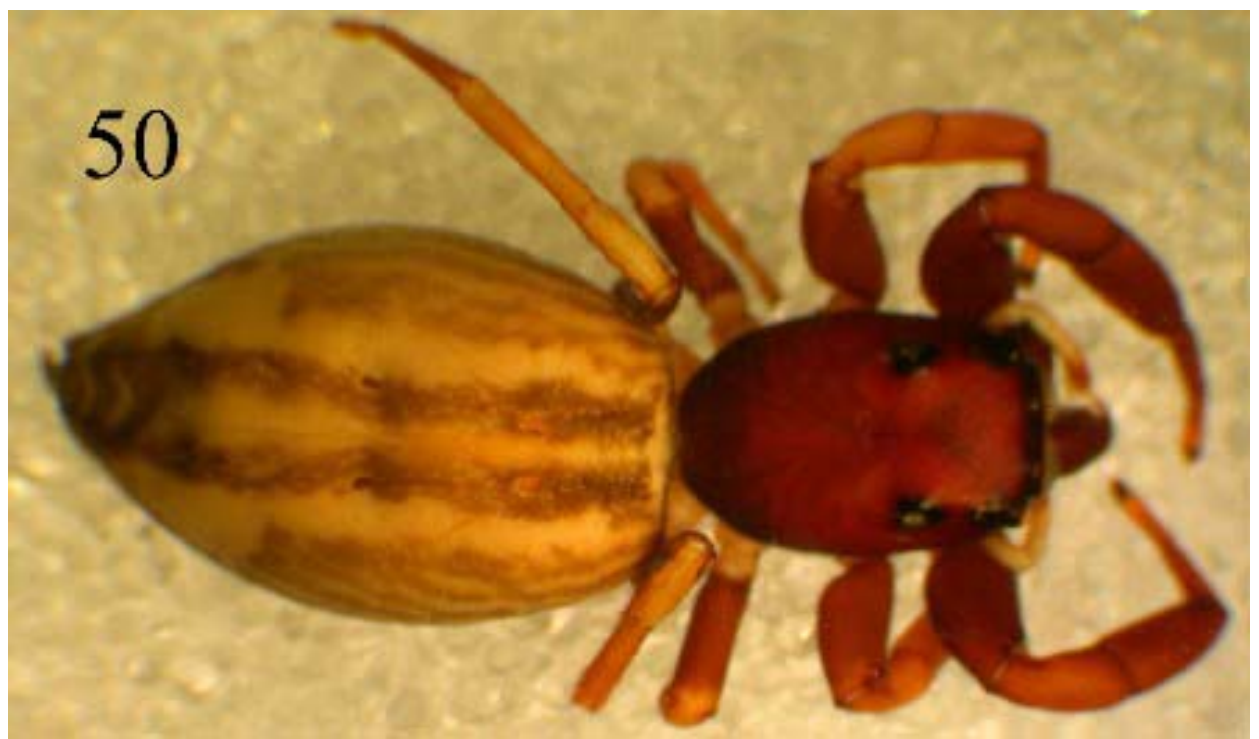

Figure 50. Breda flavostriata (Breda nigrotaeniata holotype) female habitus dorsal view.

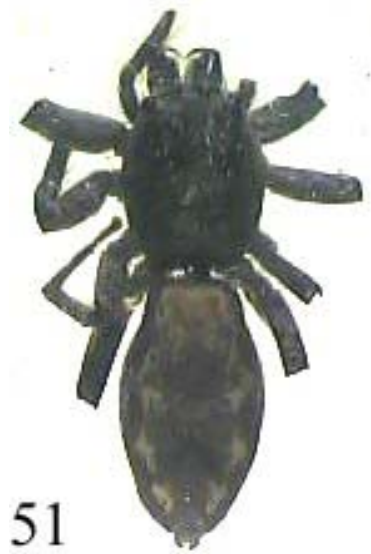

Figure 51. Platycryptus broadwayi (Naubolus aureocomosus holotype) female habitus dorsal view. 


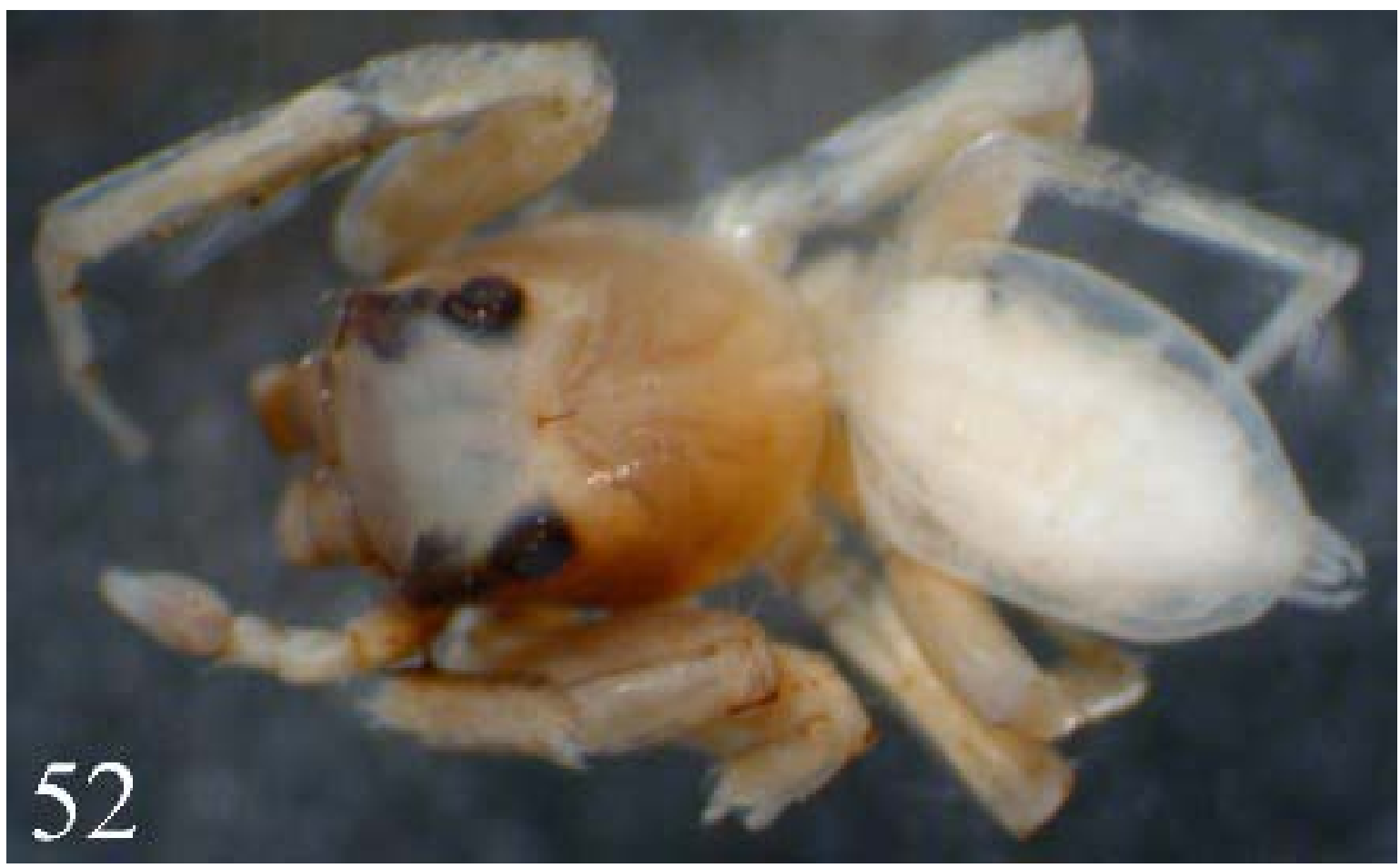

Figure 52. Coryphasia castaneipedes male habitus dorsal view.

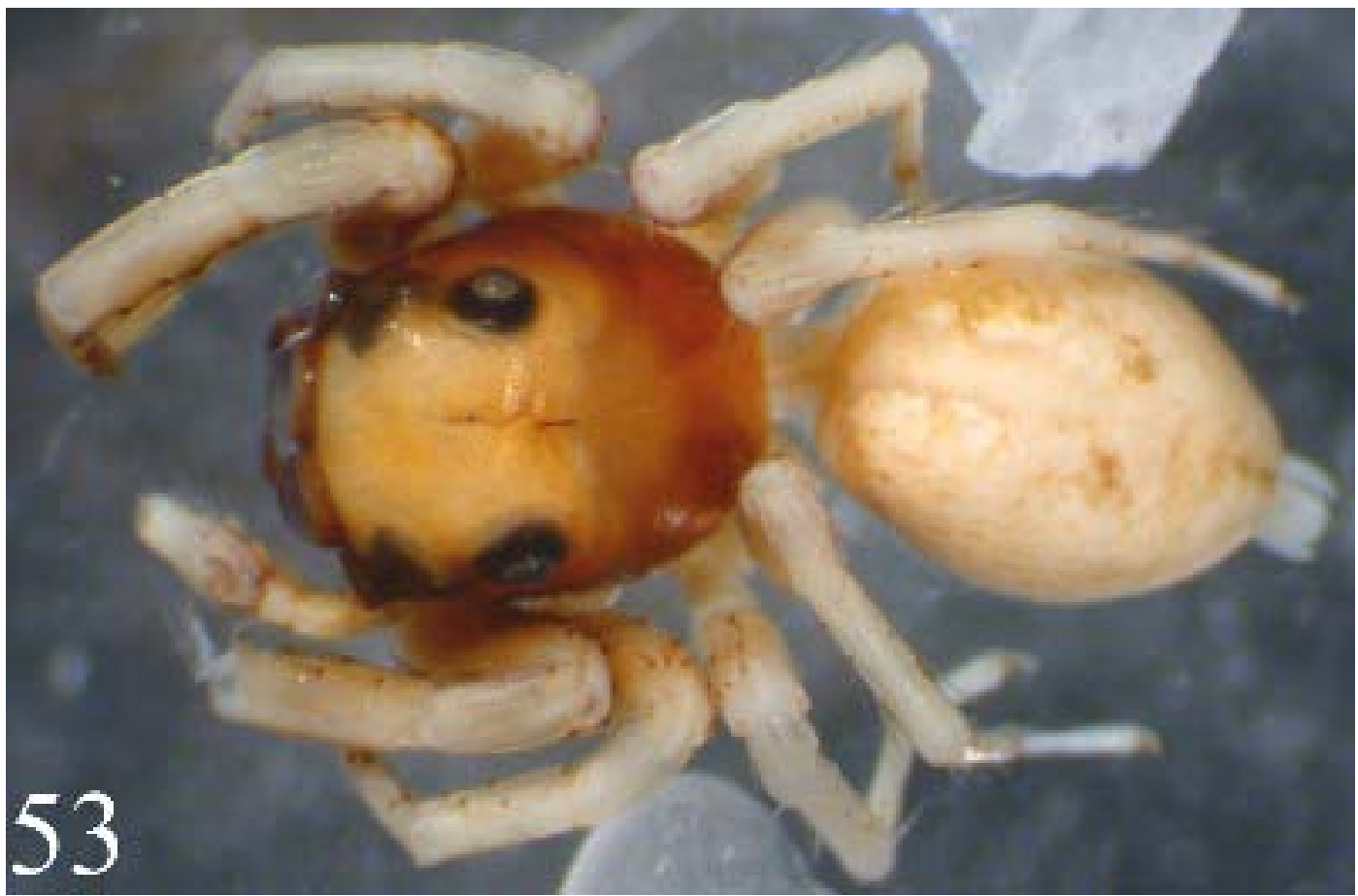

Figure 53. Coryphasia nigriventris male habitus dorsal view. 

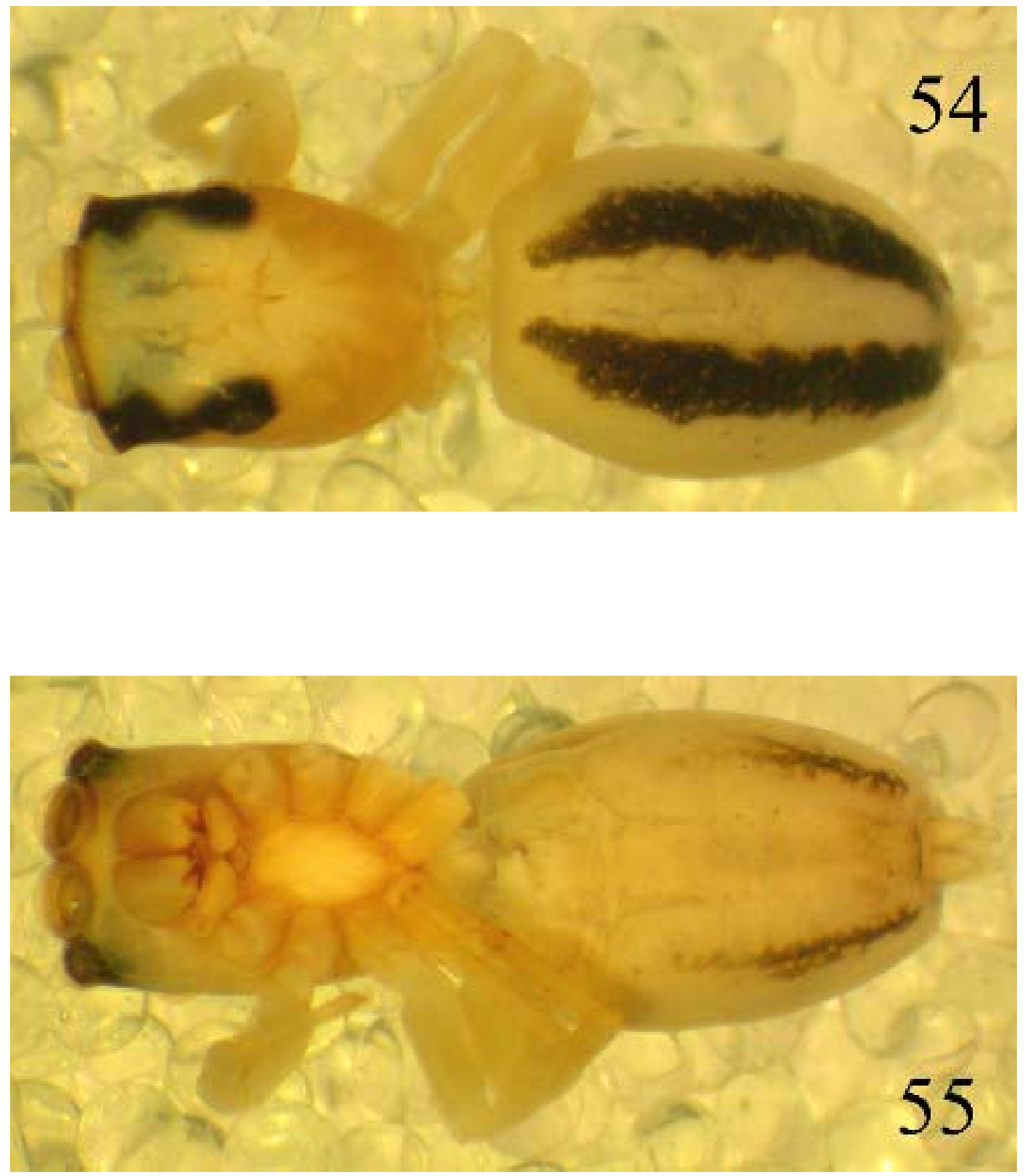

Figures 54-55: Ilargus coccineus (Akela quinquevittata holotype) 54. female habitus dorsal view; 55. female habitus ventral view. 

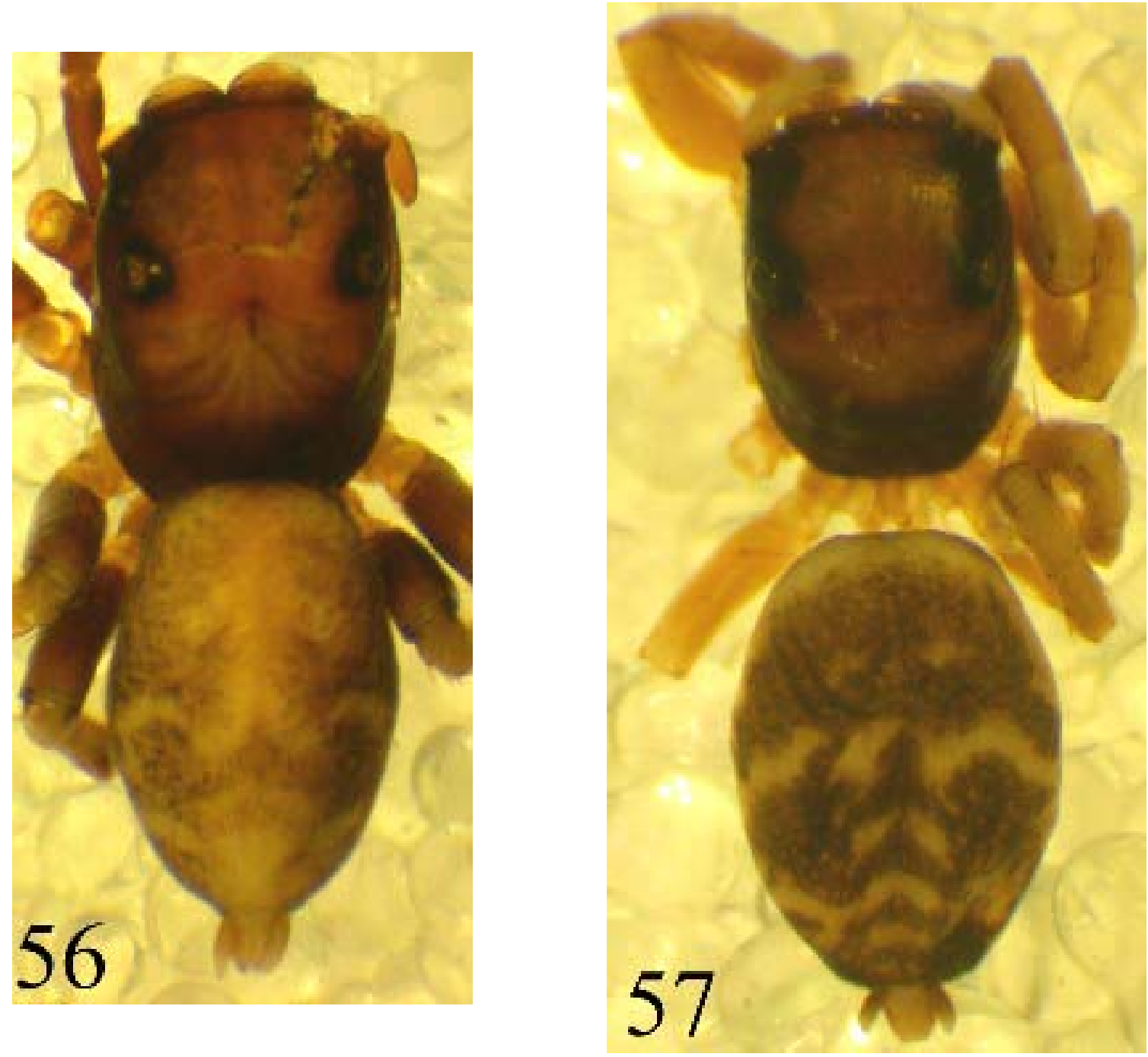

Figures 56-57: Mopiopia labyrinthea 56. male habitus dorsal view; 57. female habitus dorsal view. 


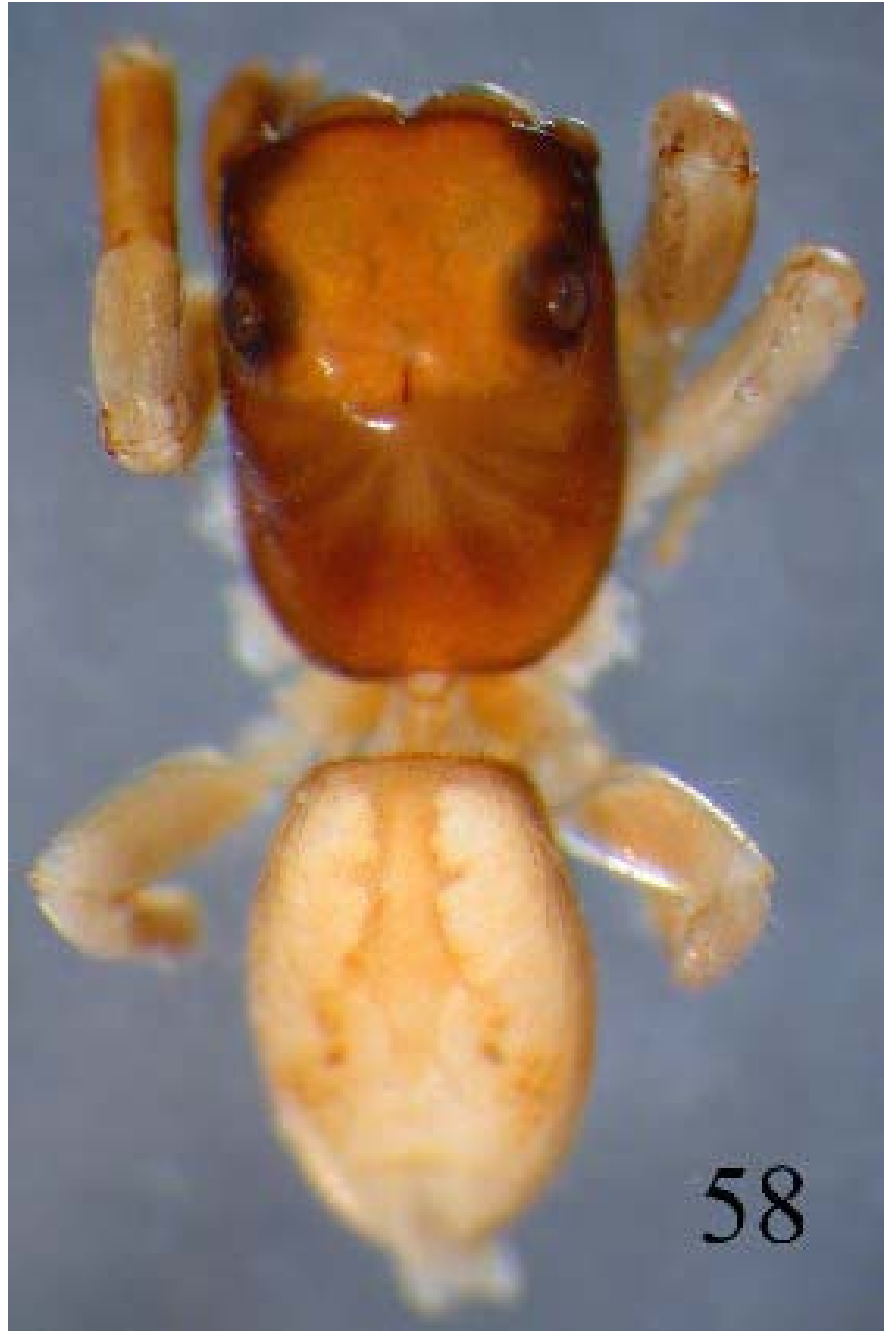

Figure 58. Mopiopia tristis male habitus dorsal view.

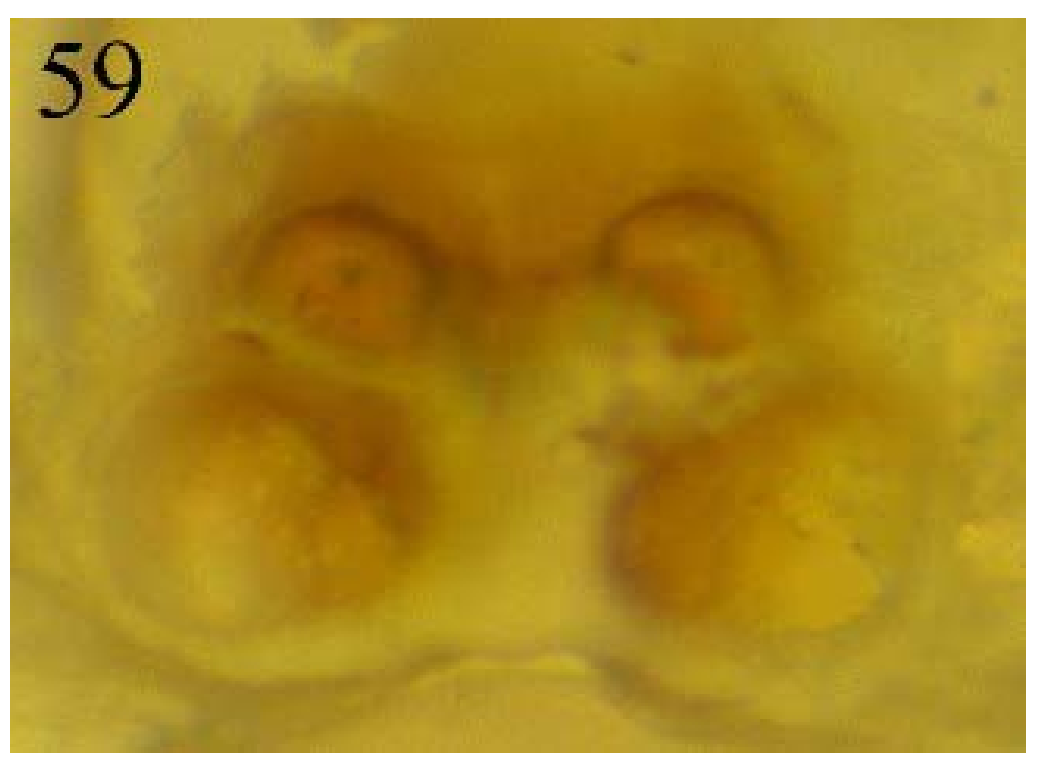

Figure 59. Chira thysbe (Asaracus elegantulus holotype) female epigynum ventral view. 


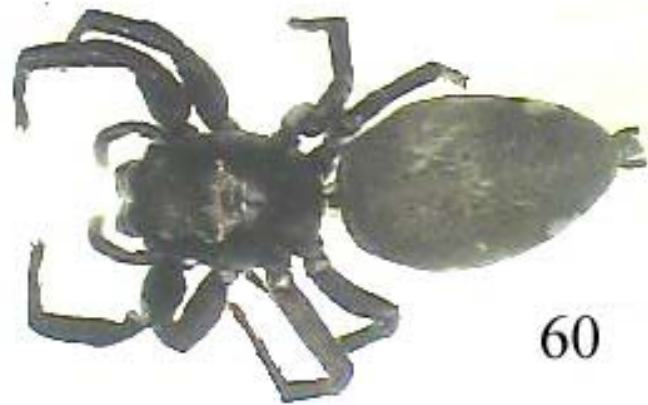

Figure 60. Phiale bipunctata female habitus dorsal view.

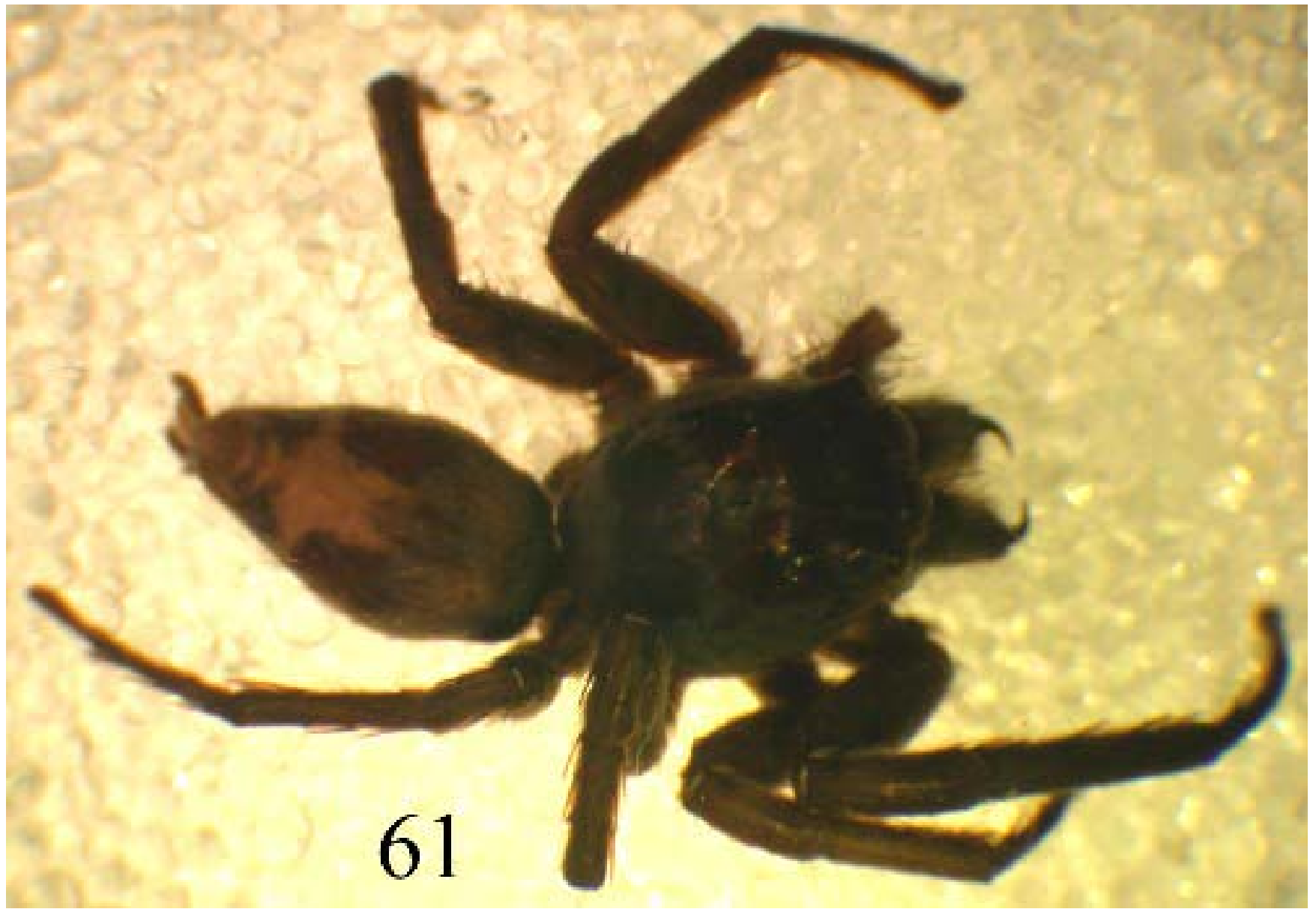

Figure 61. Phiale longibarba male habitus dorsal view. 
For purposes of discussion, the genera are sorted to higher taxonomic group (e.g., subfamily) and arranged alphabetically within each higher group [see Maddison \& Hedin (2003) for a recent reorganization of the Salticidae based on molecular analysis, which largely corroborates a previous partial classification of the Salticidae based on palpal structure (Proszynski 1976)]. Literature cited follows the World Spider Catalog (Platnick 2005).

\section{Taxonomy}

\subsection{Amycoida: Incertae Sedis}

Titanattus pallidus Mello-Leitão 1943

Figs. 1-3, 44-46

Titanattus pallidus Mello-Leitão 1943: 265 (Dm).

Type material: Holotype male, MNRJ \#01161.

Type locality: Brasil: Est. Rio de Janeiro; Pinheiral.

Comments: The genus Titanattus belongs to the large group Amycoida, possibly in the Hyetussinae. This species appears closer to the Amycinae. This species is difficult to place to genus. The chelicerae lack a mastidion present in many amycines (e.g., Galiano 1968b). The carapace shape is similar to true Titanattus, but the shape of the male palpus is atypical for this genus, similar to some species of Mago. The cheliceral dentition seems to be close to the genus Albionella, but the type species of Albionella, A. propria Chickering (1946) from Panama, is only known from the female. Caporiacco (1954) described two species of Albionella from French Guiana (one from a male, the other from a female), but these have not been examined. For now, we leave the species in Titanattus.

Perhaps the tibial apophysis structure of this species (see description below) is a precursor of one method by which a bifid apophysis is formed. Loss of the thin sheet of integument between the thickened dorsal and ventral edges would leave either two apophyses or one apophysis with two prongs, depending on how much of the intervening integument was lost.

Condition: Right palp, right legs I, II and III, and left I and II separated from body, broken, and distal pieces of legs missing.

Measurements: AERW= 1.45; $\mathrm{PERW}=1.45$; $\mathrm{LOQ}=$ 1.30; $\mathrm{PMEP}=45 \% ; \mathrm{CL}=2.55 ; \mathrm{CW}=2.10 ; \mathrm{CH}=1.45 ; \mathrm{AL}=2.95$; $\mathrm{TBL}=5.45$. Carapace brown, except upper cephalic area pale (extending onto top edge of thoracic slope). Lateral and posterior areas probably moderately covered with gray or white scales (specimen rubbed, remaining patches of scales distributed randomly). Area between ALE and PME brown, PLE ringed with dark brown (probably black originally). Fovea in depression just below and behind PER. Thoracic slope moderately steep.
Chelicerae yellowish brown, paturon length about equal to face height. Inner distal anterior margin of paturon lobed, creating a slight concavity proximal to the lobe. Promarginal row of moderately small teeth situated on lobe, with 6 teeth on the left chelicera, 5 on the right. Retromarginal row overall set closer to base of fang, with 5 teeth on the left chelicera, 4 on the right plus extended keel reaching position opposite to medial promarginal tooth on same side. The three median retromarginal teeth each side same size as promarginal teeth, the one or two teeth closest to base of fang tiny. Fang with slight bump on outer edge about $40 \%$ of length from base of fang.

Clypeus in middle almost exactly the height of an AME, laterally slightly more than AME. Broad white band of scales covering all but lower edge, extending onto cheeks. Long fringe of white hair, as wide as both AME and slanted toward middle, forming a triangular "moustache" just overlapping base of chelicerae.

Labium, sternum, endites yellowish brown. Endites lack anterolateral cusp. Anterior edge of sternum concave, posterior shallowly pointed.

Palpi semi-transparent, no evidence of notable scale patterns or fringes. Patella longer and a little wider than tibia, femur curved somewhat near the proximal end. Embolus directly emergent from and contiguous to tegulum. Tibia at first glance apparently with two moderately short retrolateral apophyses: in ventral view, a stout, pointed, inward pointing apophysis; in lateral view, with an additional dorsolateral apophysis that has the tip (seen from dorsal view) curved toward the prolateral side. This tip apparently fits into the side of a broad, truncate, proximal projection on the dorsum of the cymbium. However, the intervening space between the two "apophyses" is filled with a thin sheet of integument, making the whole structure one broad apophysis. There is also a short dorsoprolateral tibial projection, which, with the dorsal side of the retrolateral apophysis, effectively brackets and therefore probably braces the cymbial projection, perhaps during mating.

Legs semi-transparent, no evidence of notable scale patterns or fringes. Leg formula probably 1243, all legs long. Macrosetae: Leg III F d 0111, dp 0001, dr 0001; P dp 1, dr 1; T v 202, p 001, r 011; M v 203. Leg IV F d 0111, dp 0001, dr 0001; P dp 1, dr 1; T v 002, p 001, r 011; M v 21r3, p 001, r 001.

Abdominal dorsum pale, with brown heart mark between two pair of small brown maculae, rubbed free of setae but with relatively few setal sockets. Sides with apparent multiple short striae, but possibly an artifact of preservation. Venter entirely pale. 


\subsection{Amycoida: Thiodininae}

Cotinusa leucoprocta (Mello-Leitão 1947)

Figs. 4-7, 47

Itata leucoprocta Mello-Leitão, 1947: 299, pl. 42,

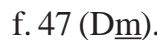

\section{C. l., Galiano 1980: 39 (Tw from Itata).}

Type material: MHNCI \#2487, holotype male.

Type locality: Brasil: Est. Paraná; Curitiba, Barigui, R. Lange leg.

Distribution: Brasil.

Comment: This species was placed in Cotinusa by Galiano (1980b), but this placement is questionable for several reasons.

Condition: Legs I and II missing, left palp missing.

Measurements: AME 0.56, AERW 1.48, PERW 1.42, LOQ 0.96, PMEP 48\%, CL 2.28, CW 1.76, CH 0.77, AL 3.09. Carapace, chelicerae, endites, labium, submedian pair of maculae in middle of abdominal dorsum light yellow brown, patches around eyes except AME darker yellow brown, OQ yellow. Otherwise spider white, legs with transparent integument. Entire spider severely faded. Lateral carapace file typical of Cotinusa not visible (at 80x). Clypeus very narrow, less than 1/10 diameter of AME.

Chelicerae length about equal to diameter of AME. Retromargin with two small contiguous teeth on medial corner. Promargin with one small tooth a little distal to retromarginal teeth, but still far from fang joint.

Endites rounded distally, without cusps, laterally concavity so short as to be almost a notch. Labium a little wider than long.

Palp with three retrolateral tibial apophyses: a moderate, narrow, ventral one pointed toward venter; a larger, narrow triangular one near dorsum pointed toward dorsum; and a long, narrow, spatulate one outside of the more dorsal of the other two, originating more medial and proximal, pointing distally (Cotinusa typically have two retrolateral tibial apophyses). Embolus originating at base on proximal side, slender but broken with tip missing, total length unknown. Compressed, winding duct distal to tegulum, as in typical thio-dinines.

Leg formula: 431?2? Macrosetae [macrosetae and their bases transparent and difficult to see, even at 100x]: III F d 0111, p 0011, r 0001; Pr 010; T v 0102, p?, r?; Mv ?02, p 102, r ?02; IV F d 0111, p?, r 0001; P r?; T?; Mv ?02, p ?02, r 102.

\subsection{Marpissoida: Dendryphantinae}

Naubolus trifasciatus Mello-Leitão 1927

Figs. 8-9, 48

Naubolus trifasciatus Mello-Leitão 1927: 408, pl. 15, f. 4-6 (Dm).
Type material: MZSP\#828, holotype male.

Type locality: Brasil: Est. Santa Catarina; Blumenau.

Distribution: Brasil.

Comments: This species seems close to South American species of the genus Sassacus, but as the neotropical dendryphantines are relatively poorly known, we hesitate to make any change in placement here.

Condition: Right palpus broken at femur/patella and distal part lost.

Measurements: $\mathrm{PMEP}=40 \%$. Carapace suboval, moderately low and flat. PER slightly wider than AER. Fovea behind PER. Upper dorsum orange, orange brown posteriorly and darker laterally. Upper dorsum continues as postocular extension past PER a distance about equal to LOQ. White scales form broad submarginal bands which extend from ALE to about half way down thoracic slope. Diameter of AME about 2.5 times the diameter of ALE. Clypeus almost nonexistent, just wide enough for a fringe of long setae.

Chelicerae a little more than half the length of the carapace, considerably porrect (closer to horizontal than vertical), cylindrical (but narrowed in distal 2/5) with a notch at base. Two narrow teeth on promargin, and one very long retromarginal tooth bent at base and pointed toward fang base. Fang long and sinuous.

Labium longer than wide. Endites dilated anterolaterally with large blunt cusp. Sternum about 1.5 times longer than wide, narrowed anteriorly and posteriorly, anterior edge subtruncate. Chelicerae, labium, and endites dark orange. Endites and labium pale on anterior edges. Sternum yellow.

Palpi yellow. Retrolateral tibial apophysis small and curved toward venter. Tegulum with large proximal prolateral projection. Embolus retrolateral, long and curved. ["Patellae cylindrical longer than wide; tibia dilated on apices, wider than long with short internal apical apophysis acute and slightly curved; tarsus long than patellae + tibia with a large basal bulb and a short apical stylet"].

Leg formula: 1423. Macrosetae: Leg I \& II F d0111, p0002; T v0222; M v022; Leg III F d0111, p0002, r0001, T v0002; M v002, p02, r01; Leg IV F d0111, r0001, T v0002; M v002, p02, r01 Leg I heavier than others. Coxae I mostly dark brown, II, III and IV yellow. All coxae dilated at base medially, especially leg I. All femora almost entirely dark orange brown. Leg I distal segments orange brown. Legs II-IV yellow distally with rings of brown on distal edges of patellae and tibiae, and proximal and distal edges of metatarsi. Proximal pair of ventral macrosetae on tibia I offset, with macroseta toward the retromarginal side in more proximal position.

Abdomen oblong, about 2.5 times longer than wide, rounded behind. Dorsal pattern with two brown bands on variegated yellow, broken posteriorly by 2 pair of short, oblique, linear spots. White hairs and scales bordering outer edges of brown bands, forming narrow lateral white stripes. 
Lateral sides with a variegated dark brown band. Venter uniformly yellow. Spinnerets yellow, except brown dorsally on posterior laterals. Anal tubercle white.

\section{Pseudofluda pulcherrima Mello-Leitão 1928}

Figs. 10-13

Pseudofluda pulcherrima Mello-Leitão, 1928: 53 (Dm).

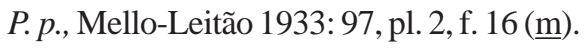

Type material: MNRJ \#1004, holotype male.

Type locality: Brasil: Est. Rio de Janeiro; Petrópolis.

Distribution: Brasil.

Comments: The palpal morphology conforms to the Dendryphantinae and makes this the only other good morphological ant mimic besides the genus Bellota known in this subfamily, although there are other marpissoid ant mimics (particularly genera placed in the Synagelinae).

Condition: Left palp, left legs I, II, and right leg II lost. Right palp separated from body.

Measurements: AERW= 0.80; $\mathrm{PERW}=0.90$; $\mathrm{LOQ}=$ 0.80; $\mathrm{PMEP}=45 \% ; \mathrm{CL}=1.65 ; \mathrm{CW}=0.90 ; \mathrm{CH}=0.50 ; \mathrm{AL}=1.80$. Carapace dark brown, trapezoid, narrower behind, flattened, pars cephalica longer than pars thoracica. Fovea twice its length behind PER. Pars cephalica light brown posteriorly separated from pars thoracica by a transverse procurved line of white scales. Black rings around eyes. Clypeus almost nonexistent with a single row of long white hairs.

Chelicerae small, one large tooth on promargin with small adjacent medial tooth, and one large basal tooth on retromargin.

Sternum and endites yellow, labium darker. Sternum elliptical, 2.5 times longer than wide, pointed behind. Endites broadly dilated distally with a small, acute anterolateral cusp.

Palpi: Patella similar to tibia. Tegulum kidney shaped, reaching middle of tibia. Embolus bifid, short and curved, distal in position. Typical dendryphantine tegular shoulder present. Retrolateral tibial apophysis short and acute.

Length formula: 143?. Macrosetae: Leg I F d0111; T v0222; M v022 [Tibia I with 2-2-2-2]. Leg I heavier than others, femur convex dorsally. Coxae yellow. Femur I light brown, other segments yellow. Leg IV yellow, with black stripes on prolateral and retrolateral parts of segments except patella. Patella IV with distal dorsal black spot.

Abdomen elliptical, constricted dorsally in the middle. Dorsum straw yellow on proximal half, distal half darker with metallic scales [“purple and green”]. Lateral sides with dark wrinkles, lightened on the constriction. Venter straw yellow, book lungs darker.

\section{Semora langei Mello-Leitão 1947}

Figs. 14-16, 49

Semora langei Mello-Leitão 1947: 302 (Dm).
Type material: MHNCI \#2481, holotype male.

Type locality: Brasil: Est. Paraná; Curitiba, Caiobá (Bariguí), VI-1944, R. Lange leg.

Distribution: Brasil.

Comments: The palp appears to put this species in the Dendryphantinae. The type species of this poorly known genus, S. napaea Peckham \& Peckham 1892, described from a female, has an epigynum which also appears to be dendryphantine.

Condition: Most of left leg I, left leg II, and right leg III missing. Right fang missing, left fang broken with only proximal stub remaining, probably moderately long.

Measurements: AME 0.40, AERW 1.14, PERW 1.20, LOQ 0.86, PMEP 53\%, CL 1.94, CW 1.39, CH 0.74, AL 2.96. Carapace orange brown w/ black around eyes except AME. Labium and fang remnant yellow brown, palpi, endites, sternum, and legs yellow, except leg II-IV coxae, trochanters, and tarsi white, and legs III-IV distal femur, patella, and tibia lateral surfaces dusky. Clypeus virtually non-existent, AME take up almost entire height of face.

Chelicerae length about 2x diameter of AME. Fang groove broad, long, and twisted toward median surface. Promargin with two teeth, one small one near fang joint, and one tiny tooth proximally, covered by endite. Retromargin with one large, slender tooth curved toward fang.

Endites truncate distally, with small, pointed anterolateral cusps extending past truncation; deeply notched laterally. Labium longer than wide, but still wider than anterior edge of narrow sternum.

Macrosetae: I F d 01110, p 0002; T v 01r1p22; M v 022; II F d 01110, p 0001; T v 01r02; M v 022; III F d 01110, p 0001, r 0001; T v 0002, p, r; M v 002, p 002, r 002; IV F d 01110, p 0001, r 0001; T v 0002, p, r; M v 002, p 002, r 002. All macrosetae moderately short and stout, remarkably lacking in places, especially on tibial lateral surfaces. Tibia I slightly thickened, but less than half as wide as long.

Abdomen: Dorsum yellow, with faint brownish infusion except in narrow sagittal area covering about posterior 3/4. Sides wrinkled. Venter white. Spinnerets brown except ALS and PMS with white tips.

\subsection{Marpissoida: Marpissinae}

Breda flavostriata Simon 1901

Figs. 17-18, 50

Breda flavostriata Simon 1901: 156 (D互).

Breda nigrotaeniata Mello-Leitão 1947: 297, pl. 39, f. 44, pl. 40, f. 45(DI); NEW SYNONYMY

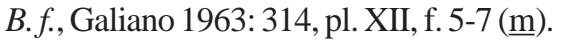

Type material (for Breda nigrotaeniata): MHNCI \#2488, holotype female. 
Type locality: Brasil: Est. Paraná; Matinhos (Caiobá).

Distribution: Brasil.

Comments: One of us (GRSR) has examined a male specimen of $B$. flavostriata and determined that it has a habitus like B. nigrotaeniata, therefore prompting this synonymy. Apparently this species is not a true Breda, but we are uncertain where to place it. It has very short leg macrosetae, a spiraloid tegulum/embolus combination, and an epigynum crossing the epigastric furrow, as occurs in the marpissine genus Fuentes. The overall dorsoventral flattening of the body is a common marpissoid character as well. However, this particular epigynal feature also occurs in some Freya group members. A pair of retrolateral tibial apophyses also occurs in some amycoids and freyines. Amycoids also sometimes have a spiraloid tegulum.

Condition: basal junction of right chelicera broken, tip of left chelicera damaged.

Measurements: AERW= 3.90; $\mathrm{PERW}=3.50$; $\mathrm{LOQ}=$ 1.95; $\mathrm{PMEP}=45 \% ; \mathrm{CL}=5.75 ; \mathrm{CW}=4.65 ; \mathrm{CH}=2.70 ; \mathrm{AL}=9.65$. Carapace oval, flattened, fovea just behind the PER. Carapace reddish-brown, posterior edge darker ["black with black striae toward pars cephalica”]. Black rings around eyes. Clypeus narrower than 1/8 diameter of AME.

Chelicerae same color as prosoma, promargin with 6 [“5”] smaller teeth in a row plus a larger one on the distal median corner, retromargin with one very broad black tooth.

Labium, sternum and endites the same color as prosoma, sternum slightly lighter in color, and anterior edge of endites pale. Labium slightly longer than wide, rounded. Sternum oblong, two times longer than wide, narrowed between coxae I. Endites convergent, truncate distally. Palpi pale, brownish distally.

Leg formula: 4123. Macrosetae: all very small but stout. Leg I \& II F d0001, p0001; T 0001p; M 002; Leg III F r0001; P r1; T v0002, r0001; M v002, p002, r002; Leg IV d0001, r0001; P r1; T v0002, r0001; M v002, p002, r002. Legs I heaviest, femora I and II dorsally convex. Tibiae slightly longer than patellae and larger than metatarsi. Leg I the same color as prosoma, darker than others. Coxae II to IV yellow, prolateral side and proximal edge darker. All legs unusually thick. All patellae have prolateral and retrolateral notches at proximal end of segment, and prominent slit sense organ in middle of retrolateral side.

Abdomen elliptical, truncate anteriorly, two times longer than wide. Dorsum with two narrow longitudinal slightly sinuous brown stripes within three yellow stripes which broaden posteriorly, lateral brown and yellow variegation on anterior 2/3 and three median brown chevrons just anterior to spinnerets. Venter with two narrow brown ["black"] stripes with pale between, from the epigastric furrow to spinnerets, otherwise variegated with yellow and brown (continuation of lateral areas). Spinnerets dark brown. Epigynum: Posterior edge extended into triangular shape with prominent blunt tip. Large, slit-like mediolateral openings.
Platycryptus broadwayi (Peckham \& Peckham 1894), NEW COMBINATION

Figs. 19-20, 51

Marptusa broadwayi Peckham \& Peckham 1894: 89,

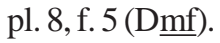

Marpissa b., Simon 1901: 603.

Naubolus aureocomosus Mello-Leitão 1943: 264 (D卢).

Marpissa b., Galiano 1981a: 11 (S).

Type material (for Naubolus aureocomosus): MNRJ \#1043, holotype female.

Type locality: Brasil: Est. Pernambuco; Tapera.

Distribution: Trinidad to Brasil.

Comments: Galiano (1981a) synonymized MelloLeitão's species with the earlier name of Peckham \& Peckham (1894). However, she placed the species in the genus Marpissa, which had been a catchall for marpissines. The North American marpissines had earlier been revised by Barnes (1958), and one of the genera, Metacyrba, had been subsequently divided by Hill (1979) with the description of Platycryptus. This species belongs in the latter genus. Figures are provided.

\subsection{Salticoida: Euophryinae}

Asaphobelis physonychus Simon 1902

Asaphobelis physonychus Simon 1902: 384 (D吕).

A. p., Simon 1903: 801, f. 932 (互).

A. pluripunctatus Mello-Leitão 1947: 295, pl. 42, f. 42

(D)f); NEW SYNONYMY

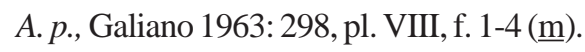

A. p., Prószyn'ski 1976: 153, f. 202 (뜨).

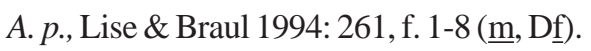

Type material (for A. pluripunctatus): MHNCI \#2459, holotype female.

Type locality: Brasil: Est. Paraná; Curitiba.

Distribution: Brasil.

Comments: Lise \& Braul (1994) previously illustrated the female and reillustrated the male.

Diagnosis: Asaphobelis can be distinguished from Coryphasia by the shape of the embolus. In Coryphasia, the embolus is a long free spiral with a small basal embolar disk (a widened area at the proximal end of the embolus). In Asaphobelis, the free part of the embolus is relatively short and stout, and is accompanied by a stout fulcrum. It also lacks a discernible embolar disk, instead continuing basally as a sclerotized outer edge to a circular membranous area. Both genera have a single bicuspid retromarginal cheliceral tooth. The palpal characters are deemed sufficiently different so that both genera should be maintained. 
In order to fully resolve the genus Asaphobelis, we include the following change, thus leaving Asaphobelis as a monotypic genus.

\section{BINATION}

Coryphasia fasciiventris (Simon 1902), NEW COM-

Asaphobelis fasciiventris Simon 1902: $385(\mathrm{Dm})$.

A. f., Galiano 1963: 296, pl. VIII, f. 5-8 (mf).

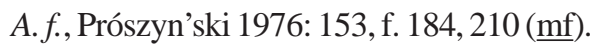

Type material: MNHN, Paris, holotype male.

Type locality: Brasil: Est. Minas Gerais; Caraça.

Distribution: Brasil.

Comments: This species was illustrated by Galiano (1963). It compares favorably to two other species of Coryphasia described by Simon and illustrated in the same publication.

\section{Coryphasia castaneipedis Mello-Leitão 1947}

Figs. 21-24, 52

Coryphasia castaneipedis Mello-Leitão 1947: 298 (D互).

Type material: MHNCI \#2593, holotype male. [Galiano (1980) states this should be 2539, but present label in vial is 2593 as in original description; as the vial no longer has a vial number as reported by Galiano (1980), the label was probably changed (all the labels in the types from this museum appear to be relatively new)].

Type locality: Brasil: Est. Paraná; Volta Grande, Piraquara, IV.1943, R. Hertel leg.

Distribution: Brasil.

Comments: This species is very unusual in that the bicuspid retromarginal tooth has been broken into two separate teeth. Otherwise, in body form and palpal structure, it appears to be a typical species of Coryphasia. The types of both this species and $C$. nigriventris are faded in color, although the latter species has more discernible color pattern.

Condition: Right palp, and distal three segments of left legs I and II missing (proximal half of tibia I present).

Measurements: AME 0.62, AERW 1.98, PERW 1.85, LOQ 1.23, PMEP 59\%, CL 2.78, CW 2.35, CH 1.73, AL 2.90. Entirely white except most of carapace, chelicerae, endites, labium and prolateral surfaces of leg I femur, patella, and tibia, light yellow brown. OQ white, black tubercles around all eyes except yellow brown around AME. Clypeus 1/5 diameter of AME.

Chelicerae length $1.7 \mathrm{x}$ diameter of AME. Dorsoventral compression at about $3 / 4$ of length, with lateral striae at compression (no obvious palpal femoral structure that would indicate a stridulatory mechanism). Promargin with two small contiguous teeth on medial corner. Retromargin with apparently two teeth, closer to fang joint than to other teeth, that seems to be a division of one large semitruncate tooth; larger part broader basally, with pointed cusp on medial corner, outer corner rounded.
Endites with short, rounded, anterolateral cusp; concave laterally. Labium longer than wide, narrower than sternum anterior edge.

Palp: faint embolar disk dorsodistally, from which embolus arises ventrodistally. Tegulum narrowed posteriorly to blunt prolateral point bent toward prolateral side. Tibial apophysis of moderate length, tip truncate. No ventral tibial apophysis (unusual for euophryines).

Leg formula 1432. Macrosetae [some leg macrosetae, which are typically black, are entirely colorless]: I F d 0111, p 0002, r 0001; P p 010, r 010; Tv21r1p20, p 0010, r1010; Mv 202, p 101, r 101; II F d 0111, p 0002, r 0001; P p 010, r 010; Tv 2220, p 1010, r11d10; Mv202, p 101, r 101; III F d0111, p 0002, r 0002; P p 010, r 010; Tv 02[medial]02, p 1110, r 1110, d 1000; Mv202, p 102, r 102; IV Fd 0111, p 0002, r 0002; P p 010, r 010; Tv 01p02, p 1110, r1110, d1000; M v 202, p 112, r 112. All coxae squared off medially and notched on inner edge.

Abdomen in poor condition, integument separated from internal structures, without any evidence of pattern. Specimen now probably much lighter in color than in life, likely an artifact of preservation.

\section{Coryphasia nigriventris Mello-Leitão 1947}

Figs. 25-28, 53

Coryphasia nigriventris Mello-Leitão 1947: 298, pl. 40, f. 46 (D互).

Type material: MHNCI \#2538, holotype male.

Type locality: Brasil: Est. Paraná; Curitiba, Barigui, X1944, R. Lange leg.

Distribution: Brasil.

Comments: See C. castaneipedis.

Condition: Left leg I metatarsus and tarsus, and right leg II tarsus missing.

Measurements: AME 0.62, AERW 2.04, PERW 1.91, LOQ 1.36, CL 2.75, CW 2.35, CH 1.54, PMEP 59\%, AL 2.87. Carapace yellow brown except OQ yellow, black around eyes except AME. Chelicerae, endites, labium, and femora of all legs yellow brown; sternum, palpi, and other legs segments white, except all leg I distal segments from patella yellow brown on lateral surfaces. Clypeus 1/5 diameter of AME.

Chelicerae length 1.6x diameter of AME. Promargin with 2 small teeth on medial corner, partially fused together. Retromargin with 1 large bicuspid tooth, wider distally than at base, and on edge of fang joint.

Endites with small, pointed anterolateral cusp; wider distally. Labium as wide proximally as it is long, narrowed in distal half, as wide as anterior edge of sternum.

Palp with no ventral tibial apophysis. Tegulum broad and bulbus posteriorly. Embolus much longer than C. castaneipedis. Embolar disk transverse, embolus arises ventromedially. 
Leg formula 4312. Macrosetae: I F d 0111, p 0002, r 0001; P p 010, r 010; T v 2220, p 1010, r 1010; M v 220[longer than tibials], p 101v, r 101v; II F d 0111, p 0002, r 0002; P p 010, r 010; T v 2220, p 11d10, r 11d10; M v 220, p 101, r 101; III F d 0111, p 0002, r 0002; P p 010, r 010; T v 01p02, p 1110, r 1110, d 1000; M v 202, p 102, r 102; IV F d 0111, p 0002, r 0002[outer one noticeably smaller]; P p 010, r 010; T v 01p02, p 1110, r 1110, d 1000; M v 202, p 112, r 112. Coxae like C. castaneipedis.

Abdomen mostly white but with faded yellow brown remnant of lateral and posterior variegated pattern, with enlarged white cardiac mark (about 3/5 of anterior length) medially. Venter with yellow brown patch about posterior 2/ 3 between epigastric furrow and spinnerets. Likely this marking was black in life (i.e., nigriventris), which shows how much specimen has faded (but probably not as much as C. castaneipedis type).

Ilargus coccineus Simon 1901

Figs. 29-30, 54-55

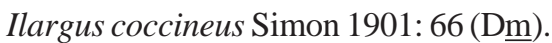

Akela penicillium Mello-Leitão 1941: 255 (Df́).

Akela quinquevittata Mello-Leitão 1947: 295, pl. 39, f. 41 (D毛, NEW SYNONYMY

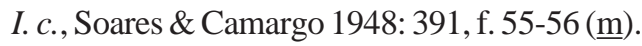

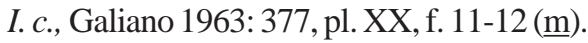

I. c., Galiano 1980: 34 (S).

I. c., Braul, Rocha-Silveira, \& Lise 1997: 144-146, f. 7-9 (Df).

Type material (for A. quinquevittata): MHNCI \#2502, holotype female.

Type locality: Brasil: Est. Paraná, Curitiba, Barigui.

Distribution: Brasil.

Comments: There is a possibility that this is the female of a different species of Ilargus, not yet recognized. Our figures of the genitalia do not quite match those given by Braul et al. (1997), but perhaps this is only due to the difference in detail. Nevertheless, a description of the type of Akela quinquevittata is provided below. The presence in A. quinquevittata of ventral, posterolateral, black abdominal stripes is typical of $I$. coccineus and supportive of this synonymy. Ilargus are similar in general appearance to Chira in the Freya group. The genital structure clearly places it in the Euophryinae, however. This is just one of many examples where convergent body forms have evolved among major groups of salticids.

Condition: Palpi and one leg I lost.

Measurements: AERW= 1.60; $\mathrm{PERW}=1.60$; LOQ= 1.05; $\mathrm{PMEP}=50 \% ; \mathrm{CL}=2.35 ; \mathrm{CW}=1.55 ; \mathrm{CH}=1.20 ; \mathrm{AL}=3.35$. Carapace rectangular, longer than wide, pars thoracica longer than pars cephalica. Fovea just behind the PER. Pars cephalica white and extending posteriorly to include the fovea, rest of carapace straw yellow. Black rings around eyes. Clypeus narrower than $1 / 3$ the diameter of AME.

Chelicerae very small, two small teeth on promargin, one tooth on retromargin (twice the size of larger promarginal tooth).

Labium, sternum and endites the same color as prosoma. Sternum twice as long as wide, widest between the coxae II and III. Labium wider than long. Endites quadrangular, dilated anteriorly.

Leg formula: 4312. Macrosetae: All F d0111; all P 0; Leg I \& II T v002, p001; M v02; Leg III \& IV T v002, p001, r001; M v02, p02, r02.

Abdomen suboval, two times longer than wide, pointed behind. Dorsum straw yellow with two black longitudinal paramedial stripes. Venter straw yellow with 2 narrow black lines on lateral edges of posterior half of abdomen. Spinnerets straw yellow. Epigynum: Two very large but faint atria, rims contiguous in the middle. Spermathecae dorsal to anterior edge of atrial rims.

Mopiopia labyrinthea (Mello-Leitão 1947), NEW COMBINATION

Figs. 31-34, 56-57

Saitis labyrintheus Mello-Leitão 1947: 301, pl. 42, f. 49, 51 (D正).

Type material: MHNCI \#2488 and \#2489, lectotype male and paralectotype female, respectively, here designated.

Type locality: Brasil: Est. Paraná; Curitiba, Barigui.

Comments: Saitis is an Old World genus. None of the New World species described in it are properly placed (Edwards 2003). Mopiopia is recognized by the distal bulge of the tegulum retrolateral to the embolus. Whether or not this character is of value at the generic level awaits detailed work on the neotropical euophryines. The color pattern in both sexes of Mopiopia tends to be dominated by the presence of abdominal chevron markings.

Male Condition: Right palpus and right leg II lost. Right leg I regenerated, now separated from body. Left leg I separated from body, broken at tibia/metatarsus joint. Left leg II broken at femur/patella, distal part missing. Left leg III broken at patella/tibia, distal part missing. Right leg IV broken at patella/tibia. Carapace fractured between AME and ALE.

Measurements: $\mathrm{AERW}=2.10$; $\mathrm{PERW}=2.05$; $\mathrm{LOQ}=$ 0.80; $\mathrm{PMEP}=50$ \%; $\mathrm{CL}=2.45 ; \mathrm{CW}=2.25 ; \mathrm{CH}=2.40 ; \mathrm{AL}=$ 2.40. Carapace [“moderately”] high, [“depressed slightly behind PE”]. AER wider than PER. Orange on upper dorsum, orange brown ["fulvous black"] posteriorly and laterally. Upper dorsum extends past PER a distance equal to LOQ. Black rings around eyes. Diameter of AME four times ["three times"] the diameter of the ALE. Clypeus bare, about 1/6 the diameter of the AME. 
Chelicerae vertical, two promarginal teeth and one retromarginal tooth.

Labium 1.5 times longer than wide, dark brown. Sternum 1.5 times longer than wide, truncate anteriorly, yellow with brown edges. Endites the same color as lateral carapace, pale on anterior edges, dilated anterolaterally with a small acute cusp.

Palpi same color as carapace. Retrolateral tibial apophysis long and slender. Slight proximal projection on ventral tibia. Tegulum with small proximal prolateral projection, sperm duct S-shaped. Embolus lacking embolar disk. Embolus very slender, 1.5 spirals.

Length formula: 143? (no complete leg II present). Macrosetae: Leg I \& II F d0111, p0002; P p1; T v0222, p0001, r0001; M v022, p 001, r001; Leg III F d0111, p0002, r0001; P p1, r1; T v0002, p0001, r0001; M v002, p 002, r002; Leg IV F d0111, p0001, r0001; P p1, r1; T v0002, p0001, r0001; M v002, p 002, r002. ["Legs I and II: femur dorsal 1-1-2, patellae 1-1, tibiae ventral 2-2-2 and 1 lateral basilar, protarsi ventral basilar apical 2-2. Legs II and IV: femur dorsal 1-1-4, patellae 1-1, tibiae 3 verticil, protarsi 2 verticil”]. Femora legs I and II heavier than III and IV, leg I uniformly brown (regenerated leg I shorter than other leg I and entirely yellow). Coxae: I mostly dark brown, II, III and IV yellow. Femora legs II, III and IV almost entirely brown. Distal segments yellow, except distal edge of tibiae and proximal and distal edges of metatarsus yellow brown. Ventrally legs II, III and IV uniformly yellow.

Abdomen suboval slightly larger than cephalothorax, 1.6 times longer than wide, rounded behind. Dorsal pattern yellow, with sinuate spots on variegated brownish ["brownish black”] anteriorly, laterally dark brown. Venter brown [“black"], anteriorly yellow. Spinnerets brown [“black”].

Female Condition: Cephalothorax separated from abdomen. Left leg II separated from body. Left leg IV broken at femur/patella joint. Right tarsus IV lost.

Measurement: PMEP = 50\%. Female smaller than male. ["Female (3.2 mm) larger than male (3.0 mm)"]. Very similar to the male except the color of the palpi and dorsal legs uniformly yellow, and metatarsi and tarsi almost entirely brown (proximal end of metatarsi and distal end of tarsi yellow).

Leg formulae: 4312? Macrosetae: Same as male, except I F r0000. ["Legs I and II: femur dorsal 1-1-2, patellae 11, tibiae ventral 2-2-2 and 1 lateral basilar, protarsi ventral basilar apical 2-2. Legs II and IV: femur dorsal 1-1-4, patellae 1-1, tibiae 3 verticil, protarsi 2 verticil”].

Venter of abdomen yellow with longitudinal median brown stripe narrowing from epigastric furrow toward but not quite reaching spinnerets. Epigynum: Small with complex surface structure. Strong rims surround large copulatory openings in which the duct opening is on the median side. The spermathecae are directly posterior to the atrial rims. The atria are mostly faintly defined, about the same size as and somewhat overlapping the spermathecae, and the median edges form a narrow septum between the openings. The ducts extend farther anterior than the openings, then turn back to the posteriorly placed spermathecae.

\section{NATION}

Mopiopia tristis (Mello-Leitão 1947), NEW COMBI-

Figs. 35-36, 58

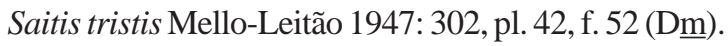

Type material: MHNCI\#2483, holotype male.

Type locality: Brasil: Est. Paraná; Curitiba, Barigui, R. Lange leg .

Distribution: Brasil.

Diagnosis: Similar to M. labyrinthea. Color pattern orange on a white background, possibly as a result of fading. Compared to M. labyrinthea, the palp has the embolus shorter with wider base, distal tegular projection more pronounced, proximal loop of sperm duct extended much more toward the prolateral side than distal loop (in M. labyrinthea, the two are about equally extended prolaterally), and proximal end of tegulum more extended.

Condition: Left leg II, both legs III, and metatarsus and tarsus of left legs I and IV missing.

Measurements: AME 0.37, AERW 1.17, PERW 1.11, LOQ 0.71, PMEP 47\%, CL 1.60, CW 1.27, CH 0.86, AL 1.60. Carapace, chelicerae, endites, labium, and prolateral surface of tibia I and II dark yellow brown. OQ yellow, black around all eyes except AME. Clypeus about 1/6 diameter of AME.

Chelicerae about 1.33x diameter of AME. Promargin with two teeth on medial corner, more proximal one very tiny. Retromargin with one tooth nearer fang joint. Fang groove short.

Endites with short, anterolateral cusp, broad, slightly wider distally. Labium a little wider than long, just barely as wide as anterior edge of sternum.

Palp with moderately long, narrow, pointed tibial apophysis; and ventral tibial tubercle that may interlock with proximoprolateral tegular lobe. Distoprolateral tegular lobe present typical of Mopiopia. Tegulum noticeably broadened distally. Embolar disk not apparent, otherwise embolus in general emerges like Coryphasia castaneipedis, but embolus shorter with tighter curl.

Leg spination: I F d 0111, p 0001; P p 010; T v 2022, p 1010; M v 202; II F d 0111, p 0002; P p 010; T v 1r01r2, p 1110; M v 202; III missing; IV F d 0111, p 0001, r 0001/2; P p 010, r 010; T v 01r02, p 1110, r 1110; M v 202, p 112, r 112. Legs yellow to white except as noted above, plus faint distal and proximal banding on metatarsus IV.

Abdomen: dorsum pale yellow except yellow brown band laterally (on side, not dorsum) traversing half way around from anterior end. Light yellow brown patch submedially behind midpoint maculae. Faint lateral variegation. Black partial ring around spinnerets, broken dorsally and ventrally. Venter pale yellow and unmarked. Spinnerets white. 


\section{Tariona albibarbis (Mello-Leitão, 1947), NEW COM- BINATION}

Figs. 37-39

Semora albibarbis Mello-Leitão, 1947: 31, pl. 1, f.

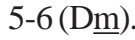

Type material: MNRJ \#2212, holotype male.

Type locality: Brasil: Est. Minas Gerais; Carmo do Rio Claro.

Comments: The type species of Semora, S. napaea Peckham \& Peckham 1892, does not appear to be a euophryine (see above). The male type of $S$. albibarbis clearly is a euophryine. The palp and body form matches the conformation of species of Tariona described by Simon (Galiano 1963), therefore we transfer the species to that genus. Tariona lack the tegular bulge present in Mopiopia, the RTA is much more slender than in the latter genus, and males are dark in color with dark legs I and pale distal leg segments on the remaining legs, similar to some species of Euophrys in the northern hemisphere.

Condition: Cephalothorax separated from abdomen. Only attached entire appendages are left palp, left legs I and IV, and right leg IV, with part of right leg II. Right palp and various leg pieces separated from body.

Measurements: AERW= 1.05; $\mathrm{PERW}=0.95$; $\mathrm{LOQ}=$ 0.55; $\mathrm{PMEP}=55 \%$; $\mathrm{CL}=1.55 ; \mathrm{CW}=1.00 ; \mathrm{CH}=0.70 ; \mathrm{AL}=$ $1.50 ; \mathrm{TBL}=3.2$ [“3.40,” apparently length of pedicel included]. Carapace dark brown, rectangular, 2.5 times longer than wide, moderately high, flat on OQ to just behind the fovea, which is behind the PER. Diameter of AME about 2.5 times the diameter of the ALE. Clypeus less than 1/4 the diameter of the AME with some long setae.

Chelicerae with two narrow teeth on inner angle of promargin (the tooth nearer the fang base is the larger), and one retromarginal tooth (about twice the size of the larger promarginal tooth) that is slightly nearer the fang base. Chelicerae, labium, and endites dark brown. Endites and labium pale on anterior edges.

Endites convergent and dilated anterolaterally. Labium wider than long. Sternum oval, about 3.0 times longer than wide, narrowed anteriorly and posteriorly. ["Sternum long, wide anteriorly with small apophyses between coxae II and III”].

Palpi: tibiae and tarsi light brown [“orange brown"]. RTA long and slender. Tegulum with proximal prolateral projection. Embolus a slender, elongated, distal spiral.

Leg formula: [“1432”]. Macrosetae: Leg I \& II F d0111, p0002; T v0222; M v022; Leg III F d0111, p0002, r0001; T v0002; M v002, p002, r001; Leg IV F d0111; T v0002; M v002, p001, r001. ["Tibiae I and II: 2-2-2 ventral, protarsi:2-2. Protarsi III and IV: two verticils.”] Legs I heavier than others and dark brown. Legs II to IV light brown [“orange brown”], with dark brown femora.
Abdomen oblong, about three times longer than wide, truncate anteriorly and pointed behind. Dorsum and venter uniformly dark brown.

\subsection{Salticoida: "Freya group”}

This major group of New World Salticidae has not been formally described. A description is in progress (Edwards, in prep. 2003).

\section{Chira thysbe Simon 1902}

Fig. 59

Chira thysbe Simon 1902: 53 (D互).

Mago taeniatus Mello-Leitão 1943: 225, f. 51 (D无).

Asaracus elegantulus Mello-Leitão 1947: 296, pl. 39, f. 43(Df), NEW SYNONYMY

Philaeus pallidus Mello-Leitão 1948: 191, f. 31 (D互).

C. pseudothysbe Soares \& Camargo 1948: 427, f. 9-10 (Dm).

C. t., Galiano 1961: 181, pl. I, f. 7-9 (뜨, S).

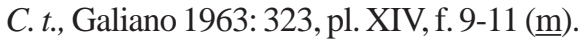

C. t., Galiano 1968a: 358, f. 9 (Df, S).

Type material (for Asaracus elegantulus): MHNCI \#2499, holotype female.

Type locality: Brasil: Est. Paraná; Marumbi.

Comments: The type of Asaracus elegantulus is in extremely poor condition; we give a description of the remainder below. However, the epigynum is in reasonably good shape. It is virtually identical in conformation to Galiano's (1968a: fig. 9) illustration of the female genitalia of $C$. thysbe.

Condition: All left legs, left chelicerae, most of right leg I and all of II lost. Right leg III broken at femur-patella joint, remainder of leg present. All remaining legs or leg pieces smashed and distorted. Carapace smashed on upper cephalic and thoracic areas. Cephalothorax and abdomen separated. Body and appendages probably dried previously.

Measurements: $\mathrm{AERW}=1.75 ; \mathrm{PERW}=1.50 ; \mathrm{LOQ}=1.05$; $\mathrm{PMEP}=40 \% ; \mathrm{CL}=2.70 ; \mathrm{CW}=1.90 ; \mathrm{CH}=1.20 ; \mathrm{AL}=3.25$. Carapace brown, pars cephalica white including all the eyes. Black rings around eyes. ["Cephalothorax cream with 4 stripes of oranges hairs, two lateral stripes from $\mathrm{AE}$ to $\mathrm{PE}$ and two more central ones from the superior edge of the AME to just behind the PE"]. Clypeus narrow, about $1 / 4$ the diameter of an AME, slanted slightly backward, with dense white semi-horizontal fringe which slightly overlaps ventral margin medially.

Chelicerae: two promarginal teeth, one retromarginal tooth (twice the size of larger promarginal tooth).

Chelicerae: two promarginal teeth, one retromargin tooth (twice the size of larger promarginal tooth).

Labium, sternum and endites the same color as prosoma. Labium longer than wide. Endites quadrangular. Sternum longer than wide. 
Leg formula: [“3 = 4”]. Macrosetae: Leg III F d0001; T v0002, p0001, r0001; M v002, p002, r002; Leg IV F d0111; T v0001r, p0001, r001, d001. ["Patellae I and II - 1 apical, tibiae I and II - 2-2-2 ventral, 1-1 anterior, metatarsi I and II - 2-2 ventral, metatarsi III and IV- 3 verticils of strong spines”]

Abdomen suboval, 2.5 times longer than wide, pointed posteriorly. Dorsum with two faint narrow sublateral stripes on white ["Abdomen white with two ferrugineus longitudinal stripes”]. Venter white. Spinnerets white. Epigynum: Two wide and deep posterior atria separated by a broad septum about 2/3 the width of an atrium containing a narrow triangular pocket. Narrow sclerotized rims separate the atria from the epigastric furrow. Copulatory openings in anteromedian edge of atria. Ducts extending more or less directly to the medial side of the spermathecae, which are each about half the size of an atrium and situated just anterior to the anterior edge of the atria, slightly toward the median.

Phiale bipunctata Mello-Leitão 1947

Figs. 40-41, 60 21 (D色.

Phiale bipunctata Mello-Leitão 1947: 26, pl. 6, f.

Type material: MNRJ \#2186, holotype female.

Type locality: Brasil: Est. Minas Gerais; Carmo do Rio Claro.

Distribution: Brasil.

Condition: Right leg III broken at patellae/tibiae, left leg I broken at femur/patellae, both separated from body. Left leg II separated from body. Labium missing.

Measurements: $\mathrm{AERW}=2.00 ; \mathrm{PERW}=2.10 ; \mathrm{LOQ}=1.55$; $\mathrm{PMEP}=50 \% ; \mathrm{CL}=3.40 ; \mathrm{CW}=2.55 ; \mathrm{CH}=1.65 ; \mathrm{AL}=5.20 ; \mathrm{TBL}=$ 8.80. Carapace purplish black, rectangular, high, fovea just behind the PER. Clypeus about 1/6 diameter of AME.

Chelicerae same color as carapace, retromargin with one very strong black tooth, nearer base of fang than two small contiguous promarginal teeth.

Sternum slightly lighter in color than carapace, oblong, two times longer than wide, narrowed and truncate anteriorly and posteriorly. Endites convergent and broadly rounded distally, anteromedial edges pale. Palpi brown.

Leg formula: 4312. Macrosetae: Leg I F d0111, p0002; T v0222, p0001; M v022; Leg II F d0111, p0002; T v0222, p0001, r0001; M v022; Leg III F d0111, p0002, r0001; P p1, r1; T v0002, p0001, r0001; M v002, p002, r002; Leg IV F d0111, r0001; P r1; T v0002, p0001, r0001; M v002, p002, r002. [“Tibiae: 2-2-2 ventral, 1-1 anterior, protarsi: 2-2 ventral, 1anterior; Protarsi II and IV : 3 verticiles”]. Legs I and II heaviest, femora legs I and II prolaterally concave. Patellae slightly shorter than tibiae. All legs the same color as prosoma.

Abdomen oval, 2.5 times longer than wide. Dorsum brown with variegated yellowish speckling, a pale stripe [“scales”] bordering anterolateral 3/5; at 3/4 posteriorly along same line a large pale spot of white scales surrounded by a ring of black scales. Venter with a conspicuous spiracle, dark yellowish brown, two faint submedial longitudinal lines made of minute yellow spots, ending somewhat anterior to spiracle. Spinnerets dark brown. Epigynum: A pair of sclerotized triple spirals descend into deep atria. Posteriorly the middle is depressed with higher areas to each side which project slightly posteriorly, somewhat like the Freya decorata group (Galiano 2001). The spermathecae are oval, touching near their posterior ends, and along the posterior edge, with a spiral duct laterally each side.

Phiale longibarba (Mello-Leitão 1943), NEW COMBINATION

Figs. 42-43, 61

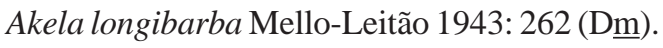

A. longobarba (sic), Roewer 1955: 1171.

Type material: MNRJ \#1022, holotype male.

Type locality: Brasil: Est. Pernambuco; Tapera.

Distribution: Brasil.

Comment: This species appears related to Phiale formosa (Banks 1909) from Central America.

Condition: Palpi and left leg I separated from body, left leg IV missing. Left posterior spinneret broken.

Measurements: $\mathrm{AERW}=2.60 ; \mathrm{PERW}=2.55 ; \mathrm{LOQ}=$ 2.10; $\mathrm{PMEP}=45 \% ; \mathrm{CL}=4.45 ; \mathrm{CW}=3.65 ; \mathrm{CH}=2.00 ; \mathrm{AL}=4.80$; $\mathrm{TBL}=9.25$. Carapace dark brown ["black”], elliptical, low, longer than wide, pars thoracica longer than pars cephalica. Fovea long, just behind the PER. Dense white hairs around fovea, around AME, lateral and posterior edges, and clypeus. Clypeus very narrow, with long white setae and two central spiniform setae curled upward.

Chelicerae with two promarginal teeth (one small, one larger closer to fang base), and one retromarginal tooth closest to fang base.

Labium two times longer than wide, rounded on tip. Sternum elliptical, two times longer than wide. Endites quadrangular, dilated anteriorly. Labium and endites the same color as prosoma. Sternum and anterior edge of endites dark yellow.

Palpi: Cymbium truncate on tip, and with heavy lateral fringes. Tegulum transverse, elongate drop shaped. Distal lobe of tegulum prominent and occupying central part of cymbium. RTA moderate in length, very thin in depth, and more or less an equilateral triangle in shape, with an acutely pointed tip.

Leg formula: 1423. Macrosetae: I F d0111, p0020, r0111; P p1, r1; T v0222, r0011; M v022; II F d0111, p0020, r0111; P p1, r1; T v0222, p0011, r0011; M v022, p001; III F d0111, p0120, r0002; P p1, r1; T v0222, p0111, r0111; M v002, p011, r011; IV F d0111, p0120, r0002; P p1, r1; T v0222, p0111, r0111; M v002, p011, r011. 
Abdomen oval, narrowed posteriorly, 2.5 times longer than wide. Dorsum dark brown with yellow marks: a broad, slightly recurved transverse band on proximal third, a median stripe on middle third with two paramedian longitudinal posterior prolongations, and two central chevrons on distal third. Spinnerets long, posterior medians yellow, anterior and posterior laterals dark brown.

Phiale tristis Mello-Leitão 1945

Phiale tristis Mello-Leitão 1945: 293 (Df́).

P. duplocellata Mello-Leitão 1947: 26, pl. 5, f. 18 (Df́); NEW SYNONYMY

P. mutilloides Mello-Leitão 1947: 27, pl. 6, f. 13 (Df́).

P. nigrosigillata Mello-Leitão 1947: 27, pl. 6, f. 22 (Df).

P. rubrosericea Mello-Leitão 1947: 28, pl. 6, f. 23 (Df́).

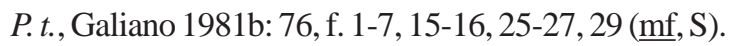

Type material (for Phiale duplocellata): MNRJ, holotype female (subadult).

Type locality: Brasil: Est. Minas Gerais; Carmo do Rio Claro.

Distribution: Argentina, Brasil, Paraguay.

Comments: The type of Phiale duplocellata is a subadult female (not adult as reported); it appears to be a juvenile specimen of $P$. tristis. As Galiano (1981b) showed, this is one of the species in this genus that has multiple color forms in the female. Several color forms were described as separate species.

\section{Acknowledgments}

We would like to thank the following curators and institutions for the loan of types: Museu Nacional do Rio de Janeiro (MNRJ) - Adriano Brilhante Kury; Museu de História Natural Capão da Imbuia (MHNCI: Curitiba) - Júlio Cesár Moura Leite; Museu de Zoologia da Universidade de São Paulo (MZSP) Ricardo Pinto da Rocha. We also wish to express our gratitude to José Mário Pisani for his illustrations of the types. A grant to GBE from the Fundação de Amparo à Pesquisa do Estado de São Paulo (FAPESP 01/13248-3) enabled a visit to UNESP (Universidade Estadual Paulista), Instituto de Biociências, Departamento de Zoologia, in Botucatu, Est. São Paulo, Brasil, to work on this project.

\section{Bibliographic References}

Banks, N. 1909. Arachnida from Costa Rica. Proc. Acad. nat. Sci. Philad. 61: 194-234.

Barnes, R. D. 1958. North American jumping spiders of the subfamily Marpissinae (Araneae, Salticidae). American Museum Novitates 1867: 1-50.

Bauab V., M. J., \& B. A. M. Soares. 1982. Contribuição ao estudo dos Salticidae (Araneae) do Brasil. IX. Revta bras. Ent. 26: 87-91.
Braul, A., M. Rocha-Silveira, \& A. A. Lise. 1997. Descrição das fêmeas de Ashtabula sexguttata e Ilargus coccineus e do macho de Euophrys saitiformis (Araneae, Salticidae). Biociências 5(2): 141-150.

Braul, A., \& A.A. Lise. 2002. Revisão taxonômica das espécies de Vinnius e a proposição de dois gêneros novos (Araneae, Salticidae). Biociências 10: 87-125.

Caporiacco, L. di. 1954. Araignées de la Guyane Française du Muséum d’Histoire Naturelle de Paris. Commentat. pontif. Acad. Scient. 16: 45-193.

Chickering, A. M. 1946. The Salticidae of Panama. Bull. Mus. comp. Zool. Harv. 97: 1-474.

Edwards, G. B. 2000. A synonym in the genus Fluda (Araneae: Salticidae). Insecta Mundi 14: 252.

Edwards, G. B. (2002) 2003. A review of the Nearctic jumping spiders (Araneae: Salticidae) of the subfamily Euophryinae north of Mexico. Insecta Mundi 16: 65-75.

Galiano, M. E. 1961. Revision del género Chira Peckham, 1896 (Araneae, Salticidae). Comun. Mus. argent. Cienc. nat. Bernardino Rivadavia 3: 159-188.

Galiano, M. E. 1963. Las especies americanas de arañas de la familia Salticidae descriptas por Eugène Simon: Redescripciones basadas en los ejemplares típicos. Physis B. Aires (C) 23: 273-470.

Galiano, M. E. 1968a. Adiciones a la revisión del género Chira Peckham, 1896 (Araneae, Salticidae). Physis B. Aires (C) 27: 349-366.

Galiano, M. E. 1968b. Revisión de los géneros Acragas, Amycus, Encolpius, Hypaeus, Mago y Noegus (Salticidae, Araneae). Revta Mus. argent. Cienc. nat. Bernardino Rividavia (Ent.) 2: 267-360.

Galiano, M. E. 1980. Catalogo de los especimenes típicos de Salticidae (Araneae) descriptos por Cândido F. de MelloLeitão. Primera parte. Physis B. Aires (C) 39: 31-40.

Galiano, M. E. 1981a. Catalogo de los especimenes típicos de Salticidae (Araneae) descriptos por Cândido F. de Mello-Leitão. Segunda parte. Physis B. Aires (Secc. C) 39: 11-17.

Galiano, M. E. 1981b. Revisión del género Phiale C. L. Koch, 1846 (Araneae, Salticidae) III. Las especies polimorficas del grupo mimica. J. Arachnol. 9: 61-85.

Galiano, M. E. 1981c. Revisión of the genus Phiale C. L. Koch, 1846 (Araneae, Salticidae). IV. The polymorphic species of the gratiosa group. Bull. Br. arachnol. Soc. 5: 205-216.

Galiano, M. E. 1981d. Revisión del género Aphirape C. L. Koch, 1851 (Araneae, Salticidae). Comun. Mus. argent. Cienc. nat. Bernardino Rivadavia (Ent.) 1: 93-111.

Galiano, M. E. 1982. Revisión del género Nycerella (Araneae, Salticidae). Physis B. Aires (Secc. C) 41: 53-63. 
Galiano, M. E. 1983. Descripción de Sumampattus nuevo género (Araneae, Salticidae). Physis B. Aires (Secc. C) 41:151-157.

Galiano, M. E. 1984a. Descripción de Wedoquella nuevo género (Araneae, Salticidae). J. Arachnol. 11: 343-352.

Galiano, M. E. 1984b. Las especies de Menemerus Simon, 1868 (Araneae, Salticidae) en la Argentina. Physis B. Aires (Secc. C) 42: 6.

Galiano, M. E. 1984c. Revisión del género Rudra Peckham y Peckham, 1885 (Araneae, Salticidae). Physis B. Aires (Secc. C) 42: 63-72.

Galiano, M. E. 1985. Revisión del género Hurius Simon, 1901 (Araneae, Salticidae). J. Arachnol. 13: 9-18.

Galiano, M. E. 1987. Descripción de Hisukattus nuevo género (Araneae, Salticidae). Revta Soc. ent. argent. 44: 137-148.

Galiano, M. E. 1988. Revisión de los géneros del grupo Hurieae (Araneae, Salticidae). J. Arachnol. 15: 285-301.

Galiano, M. E. 1992. Nota sobre dos especies de Dryphias Simon (Araneae, Salticidae). Revta Soc. ent. argent. 50: 29-41.

Galiano, M. E. 1995. Descripción de Trydarssus, nuevo género (Araneae, Salticidae). Bol. Soc. Biol. Concepción 66: 103-112.

Galiano, M. E. 2001. Revisión de las especies de Freya del grupo decorata (Araneae, Salticidae). J. Arachnol. 29: 21-41.

Hill, D. E. 1979. The scales of salticid spiders. Zool. J. Linn. Soc. 65: 193-218.

Holmberg, E. L. 1875. Descriptions et notices d'arachnides de la République Argentine. Period. zool. Soc. Ent. Argentina 1: 283-302.

Koch, C. L. 1846. Die Arachniden. Nürnberg, Dreizehnter Band, pp. 1-234, Vierzehnter Band, pp. 1-88.

Koch, L. 1867. Zur Arachniden und Myriapoden-Fauna SüdEuropas. Verh. zool.-bot. Ges. Wien 17: 857-900.

Lise, A. A., \& A. Braul. 1994. Asaphobelis physonychus Simon: Descrição da fêmea e novas contribuições para o conhecimento do macho. Revta bras. Zool. 11: 261-264.

Maddison, W. P., and M. C. Hedin. 2003. Jumping spider phylogeny (Araneae: Salticidae). Invertebrate Systematics 17: 529-549.

Mello-Leitão, C. F. de. 1922. Quelques araignées nouvelles ou peu connues du Brésil. Ann. Soc. ent. Fr. 91: 209-228.

Mello-Leitão, C. F. de. 1927. Arachnídeos de Santa Catharina (Brasil). Rev. Mus. Paulista 15: 393-418.

Mello-Leitão, C. F. de. 1928. Novas notas arachnológicas. VI-IX. Bol. Mus. nac. Rio-de-Jan. 4(3): 49-54.

Mello-Leitão, C. F. de. 1933. Ensaio sobre as myrmarachninas do Brasil. Bol. Mus. nac. Rio-de-Jan. 9: 39-102.
Mello-Leitão, C. F. de. 1939. Araignées américaines du Musée d'histoire naturelle de Bâle. Rev. suisse zool. 46: 43-93.

Mello-Leitão, C. F. de. 1940. Spiders of the Guiana forest collected by O. W. Richards. Archos Zool. Est. S Paulo 2: 175-197.

Mello-Leitão, C. F. de. 1941. Las arañas de Córdoba, La Rioja, Catamarca, Tucumán, Salta y Jujuy colectadas por los Profesores Birabén. Revta Mus. La Plata (N.S., Zool.) 2: 99-198.

Mello-Leitão, C. F. de. 1942. Arañas del Chaco y Santiago del Estero. Revta Mus. La Plata (N.S., Zool.) 2: 381-426.

Mello-Leitão, C. F. de. 1943. Arañas nuevas de Mendoza, La Rioja y Córdoba colectadas por el Professor Max Birabén. Revta Mus. La Plata (N.S., Zool.) 3: 101-121.

Mello-Leitão, C. F. de. 1944. Arañas de la provincia de Buenos Aires. Revta Mus. La Plata (N.S., Zool.) 3: 311-393.

Mello-Leitão, C. F. de. 1945. Arañas de Misiones, Corrientes y Entre Ríos. Revta. Mus. La Plata (N.S., Zool.) 4: 213-302.

Mello-Leitão, C. F. de. 1946. Arañas del Paraguay. Notas Mus. La Plata 11(Zool. 91): 17-50.

Mello-Leitão, C. F. de. 1947. Aranhas de Carmo do Rio Claro (Minas Gerais) coligidas pelo naturalista José C. M. Carvalho. Bolm Mus. nac. Rio de J. (N.S., Zool.) 80: 1-34.

Mello-Leitão, C. F. de. 1948. Contribuição ao conhecimento da fauna araneológica das Guianas. Anais Acad. bras. Cienc. 20: 151-196.

Peckham, G. W., \& E. G. Peckham. 1892. Ant-like spiders of the family Attidae. Occ. Pap. nat. Hist. Soc. Wiscons. 2(1): 1-84.

Peckham, G. W., \& E. G. Peckham. 1894. Spiders of the Marptusa group. Occ. Pap. nat. Hist. Soc. Wiscons. 2: 85-156.

Peckham, G. W., \& E. G. Peckham. 1896. Spiders of the family Attidae from Central America and Mexico. Occ. Pap. nat. Hist. Soc. Wiscons. 3: 1-101.

Pires de Melo, A. 2003. Revisão sistemática das espécies brasileiras de Thiodina Simon, 1900 (Arachnida: Araneae: Salticidae). Master's Thesis, Universidade Federal do Rio de Janeiro. 149 pp.

Platnick, N. I. 2005. The world spider catalog, version 5.5. American Museum of Natural History, online at

Prószyn’ski, J. 1976. Studium systematycznozoogeograflczne nad rodzina Salticidae (Aranei) Regionów Palearktycznego i Nearktycznego. Wyzsza Szkola Pedagogiczna Siedlcach 6: 1-260.

Roewer, C. F. 1955. Katalog der Araneen von 1758 bis 1940, bzw. 1954. Bruxelles, 2: 1-1751.

Simon, E. 1901. Descriptions d'arachnides nouveaux de la famille des Attidae (suite). Ann. Soc. ent. Belg. 45: 141-161.

Simon, E. 1902. Description d'arachnides nouveaux de la famille des Salticidae (Attidae) (suite). Ann. Soc. ent. Belg. 46: 24-56, 363-406. 
Soares, B. A. M. \& H. F. de A. Camargo. 1948. Aranhas coligidas pela Fundação Brasil-Central (ArachnidaAraneae). Bolm Museo Paraguay Emilio Goeldi 10: 355409.

Tullgren, A. 1905. Araneida from the Swedish expedition through the Gran Chaco and the Cordilleras. Ark. Zool. 2(19): 1-81.

\footnotetext{
Title: A review of some south american species of jumping spiders(araneae: salticidae) described by melloleitão from brasil,with resolution of the genus asaphobelis

Authors: G. B. Edwards, Isabela M. P. Rinaldi, and Gustavo R. S. Ruiz

Biota Neotropica, Vol. 5 ( number 2): 2005

http://www.biotaneotropica.org.br/v5n2/pt/ abstract?taxonomic-review+bn01405022005

Date Received 12/17/2004 - Revised 03/22/2005

Accepted 07/01/2005

ISSN 1676-0611
} 